\title{
Sustaining the Buyout Governance Model: Inside Secondary Management Buyout Boards
}

\author{
R. Jelic ${ }^{\text {a) }}$ D. Zhou ${ }^{\text {b) }}$ and M. Wright ${ }^{\text {() }}$ \\ ${ }^{a}$ University of Sussex, School of Business, Management and Economics, Brighton, BN21 9SL, UK; \\ R.Jelic@sussex.ac.uk; \\ ${ }^{\mathrm{b}}$ University of Reading, Henley Business School, Whiteknights, Reading, RG6 6UD, UK; \\ dan.zhou@henley.ac.uk; \\ ${ }^{\mathrm{c}}$ Imperial College Business School, Exhibition Road, London SW7 2AZ, UK and University of Ghent, Belgium \\ mike.wright@imperial.ac.uk
}

Forthcoming in British Journal of Management

\begin{abstract}
We examine the impact of private equity (PE) directors and their human capital on operating performance in a unique hand collected sample of 200 secondary management buyouts (SMBOs) during 2000-2015. We show that PE directors' human capital tends to play statistically and economically important role in performance. Financial (rather than operational) experience of PE directors in acquiring PE firms tends to have a substantial impact on post-SMBO profitability while high level business education is especially important in post-SMBO growth performance enhancement. Complementary expertise, provided by directors in buying and selling PE firms, plays an important role only in postSMBO growth improvements. Overall, our results provide evidence that governance benefits of the buyout model tend not to be exhausted in the primary buyout stage but the effects in the secondary buyout phase depend on the nature of PE directors' human capital resource, notably in respect of the balance between board monitoring and advisory roles. Our study therefore adds to growing evidence on how ownership and life-cycle nature of firms affect sustainability of boards fulfilling their roles. The results are robust to sample selection bias, different types of PE firms and different measures of human capital.
\end{abstract}

Key words: Buyouts, boards, private equity, human capital.

JEL classification: $G 24, G 32, G 34$

Acknowledgements: We are grateful to March Goergen (editor) and three anonymous referees for their comments and suggestions. We thank participants at $16^{\text {th }}$ Workshop on Corporate Governance and Investment, Alliance Manchester Business School (December 2015) and 2015 European Financial Management Association (EFM) Annual Meeting. We are indebted to Gary Dushnitsky for providing us with the concordance that links VEIC and SIC schemes. Usual disclaimer applies. 


\section{Introduction}

Management buyouts and related transactions represent an important organizational ownership innovation enabling firm reconfiguration and reinvigoration to maintain performance (Ahlers et al., 2016; Toms, Wilson and Wright, 2015). Buyouts enhance corporate governance compared to prior owners as board and management changes (Cumming, Siegel and Wright, 2007), leverage and the alignment of managerial and shareholder incentives address agency issues (Jensen, 1989). In a secondary management buyout (SMBO), the initial (primary) buyout is acquired by new private equity (PE) financiers. SMBOs oftentimes involve changes to board membership including replacement of PE directors and existing chief executive (CEO) and chief financial (CFO) officers whilst companies remain in private ownership rather than being acquired in a strategic sale or going public. SMBOs are an ownership structure and governance mechanism that has grown in importance since the financial recession. By 2015, the extent of SMBOs was at parity with primary buyouts (CMBOR, 2016).

Despite growing research (Siegel, Wright and Filatotchev, 2011; Wang, 2012), there is a paucity of studies on SMBO corporate governance and the role of PE partners and executives on boards (PE directors). This is an important omission in light of the heated debate about short-termism and the nature of performance in PE backed buyouts (Goergen, O'Sullivan and Wood, 2014; Kaplan and Strömberg, 2009; PSE, 2007; Wood and Wright, 2010). Yet SMBOs represent a means to sustain the buyout organizational form over time and hence a novel context to examine the sustainability of corporate governance in the context of ownership evolution.

Evidence on SMBO underperformance would be consistent with the hypothesis that agency cost reduction and other benefits associated with the buyout model are exhausted in the 
primary buyout (Arcot et al., 2015; Degeorge, Martin and Phalippou, 2016). However, while previous studies report mixed evidence on SMBO performance (Achleitner and Figge, 2014; Bonini, 2015; Jelic and Wright, 2011; Wang 2012, Zhou, Jelic and Wright, 2014) they pay little attention to whether the SMBO has effective governance mechanisms, especially relating to board expertise. The ownership change in SMBOs represents a distinctive firmspecific characteristic that may impact the effective composition of boards yet understanding is lacking.

The nature of the corporate governance exercised by boards to sustain a firm may be contingent on firm-specific characteristics (Knockaert and Ucbasaran, 2013; Zona, Zattoni and Minichilli, 2013). As such, there may be a need to adopt complementary theories to understand the appropriate nature of governance (Filatotchev, 2006). Regarding SMBOs, this suggests a need for complementary theories to traditional agency theory. Human capital resources of outside directors are associated with monitoring and advice which link to strategic decision-making and firm performance (Tian, Haleblian and Rajagopalan, 2011). The strategic entrepreneurship perspective (Ireland, Hitt and Sirmon, 2003) suggests that PE directors monitor managers but also provide advisory resources to help in identifying and exploiting growth opportunities (Meuleman et al., 2009; Wright et al., 2000). SMBO performance may be associated with managers' and PE firms' motivation to employ their idiosyncratic knowledge, skills, experience, and capabilities to this end opportunities beyond the initial buyout. New blood injected into the board on SMBO, through new and more PE board representation, may enhance the firm's ability to exploit entrepreneurial opportunities. There may thus be complementarity between the need to maintain agency based monitoring and the need to enhance the strategic entrepreneurship based advisory role in terms of the available human capital resources. Hence, our first research question is: how is $P E$ 
involvement on the board associated with post-SMBO performance and how is this affected by SMBOs of underperforming primary buyouts?

Human capital brought by outside board members may vary considerably (Knockaert and Ucbasaran, 2013; Acharya et al., 2013). Prior research (Degeorge, Martin and Phalippou, 2016) treats PE directors as a homogenous in SMBOs with a focus mainly on their financial monitoring skills. Yet, some PE partners and executives may be better at financial monitoring and cost-cutting while others may be better at exploiting growth opportunities. We argue that the variety of human capital of PE directors impacts differently on monitoring and advising managers to reduce agency costs and exploit growth opportunities with consequences for post-SMBO performance. Hence, our second research question is: how does the nature of PE board members' human capital affect SMBO performance?

Using a unique hand collected sample of 200 SMBOs, we find that presence of PE directors improves SMBOs performance. PE expertise particularly matters for performance improvement in poorly performing buyouts. PE directors' financial experience and high level business education substantially impact post-SMBO profitability and growth, respectively. High level business education is especially important in the post-SMBO performance enhancement. PE directors' operational experience fails to contribute to post-SMBO performance.

We contribute firstly to the literature $f$ that suggests that the nature of corporate governance sustainability is related to the context in which it occurs by exploring the changing nature of corporate governance in the case of management buyout type transactions over time. Second, we add to the emerging literature on the dual role and human capital composition of boards 
which acknowledges the importance of recognizing firms' heterogeneous ownership structures (Zona, Zattoni and Minichilli, 2013). By examining SMBOs we show that rather than a simple linear move from resource contribution to monitoring (Eslayed, 2010), the sustainability of boards' ability to fulfill their roles (Goergen and Renneboog, 2014) depends on how they evolve their skills composition over time. Third, we contribute to calls to adopt multi-theoretical approaches to the study of boards (Filatotchev, 2006; Zona, Zattoni and Minnichilli, 2013) by extending the traditional agency theory approach to incorporate the strategic entrepreneurship perspective as a complementary theory in the SMBO context (Meuleman et al., 2009).

\section{Theory background and hypotheses development}

\subsection{Strategic entrepreneurship vs. agency perspective}

Agency theory suggests the superiority of buyout structures is rooted in high leverage, enhanced managerial incentives and active PE firm monitoring and intervention (Jensen, 1989). PE partners and executives sit on the board to monitor managers closely to ensure they focus their efforts effectively (Cornelli and Karakaş, 2013). Accordingly, performance improvement is mainly attributed to efficiency gains from reducing agency costs. However, high leverage and close financial monitoring may restrict the decisions to pursue growth opportunities associated with risky projects (Rappaport, 1990). Hence, agency theory fails to address the upside potential of buyouts (Wright et al., 2000).

The strategic entrepreneurship perspective complements agency theory (Meuleman et al., 2009). Using growth as an important indicator of entrepreneurship (Delmar, Davidsson and Gartner, 2003), this perspective recognizes the importance of resources and capabilities in identifying and exploiting growth opportunities to create value (Hitt et al., 2001). It also 
suggests the importance of an effective board in ensuring the efficiency of strategic and entrepreneurial actions (Ireland et al., 2001). The competence and skills of board members are thus essential (Hendry, 2005) and boards need to have a mix of skills (Zattoni and Cuomo, 2010; Zona, Zattoni and Minnichilli, 2013). In buyouts, PE partners and executives acting as directors may stimulate entrepreneurial growth through both monitoring management efficiency and providing resources and capabilities (Wright et al., 2000). First, managers with resources and capabilities to identify and exploit growth opportunities are motivated and monitored by PE directors to pursue risky growth opportunities to create value. From agency theory, greater managerial ownership may decrease firm value due to entrenchment and managerial risk aversion (Morck, Shleifer and Vishny, 1988). Managers may reject risky projects with high profit potential (Wright et al., 2000). Close monitoring by PE directors may mitigate this problem.

Second, PE directors may provide complementary resources and capabilities to management by advising on growth opportunities (Wright et al., 2000). PE firms' rich deal and sector experience play a significant role in improving post-buyout performance (Cressy, Munari and Malipiero, 2007; Harris, Siegel and Wright, 2005). Outside investors can provide entrepreneurial firms with resources and capabilities they lack (Filatotchev, 2006). Pressure resistant investors (Eslayed, 2010), like PE investors, may have a longer-term perspective enabling them to focus on improving growth performance through entrepreneurial actions. PE partners and executives as directors may therefore complement inside managers by facilitating access to critical resources and capabilities for growth (Meuleman et al., 2009).

Agency theory is silent on the human capital of PE directors. Human capital in the strategic entrepreneurship perspective is critical to the resources and capabilities needed for growth 
opportunities (Ireland, Hitt and Sirmon, 2003). Accumulated from education and in-job experience, the expertise and skills represent individuals' know-how regarding competing in the industry, and in identifying and exploiting entrepreneurial activities (Barney, 2014; Becker, 1975).

Directors with more, high quality human capital provide more effective monitoring and advice resulting in better performance (de Villiers, Naiker and van Staden, 2011). Human capital resources of outside directors are crucial for growing companies in helping strategy development and providing resources for growth, when incumbent management face resource and capacity scarcities (Clarysse, Knockaert and Lockett, 2007). Outside directors with complementary human capital resources can add substantial value in this direction (Kroll, Walters and Wright, 2008).

However, empirical evidence is lacking on the human capital of PE partners and executives, except for Acharya et al. (2013) on primary buyouts and Degeorge, Martin and Phalippou (2016) on SMBOs which find that financial and operational experiences of PE partners/firms contribute to financial returns. These studies mainly focus on investment performance at PE firm level, not addressing whether human capital of PE partners and executives contributes to SMBO operating performance at portfolio company level. Focusing on the PE firm as a whole ignores the contribution of the human capital of individual PE partners (and other PE firm executives) as directors of a particular SMBO.

This is crucial because PE firms usually allocate a subset of PE partners and others to manage one buyout who take board seats, providing monitoring and advice based on their own knowledge and experience. Their human capital may differ from the human capital of PE 
firm partners as a whole. Treating the PE firm as homogeneous thus overlooks the human capital heterogeneity among PE directors. We aim to address these gaps. Finally, it is not only PE partners involved in deals and are represented on boards. Our definition of PE directors includes people on PE firms' payrolls that may not necessarily be partners. Examining only PE firms partners at the PE firm level as a whole misses important aspects of the PE skills applied to specific deals.

Accordingly, we argue that PE directors act as monitors and advisors to reduce agency costs (agency theory) and facilitate identifying and exploiting profitable growth opportunities (strategic entrepreneurship perspective). Human capital of PE directors impacts the effectiveness of both monitoring and advising (Hillman and Dalziel, 2003; Knockaert and Ucbasaran, 2013). Within the SMBO context, the dual roles of PE partners and executives on the board, and their human capital, is likely to be crucial.

SMBOs continue the buyout organizational form to another life-cycle phase, implying resolving agency issues to obtain efficiency improvements should not be the main way for investors to enhance performance. Monitoring by PE directors may still be important in this secondary phase as introducing new PE investors and managerial entrenchment from their increased ownership and reduced monitoring by PE directors can create agency problems (Achleitner, Figge and Lutz, 2012; Degeorge, Martin and Phalippou, 2016). However, if efficiency gains in the primary buyout have largely been exhausted, there may be need for a greater advisory role of PE directors for entrepreneurial growth opportunities. These conditions call forth a need for SMBO boards and PE directors in particular to comprise both monitoring and adding value skills. From a strategic entrepreneurship perspective, there is likely a need for the SMBO board to possess idiosyncratic expertise to mobilize resources 
to exploit entrepreneurial opportunities successfully. There is thus a complementarity between agency and strategic entrepreneurship perspectives in understanding the role of PE directors in SMBOs (Wright et al., 2000). The heterogeneous human capital resources of PE directors may help in understanding their abilities in implementing the dual role to improve performance.

\subsection{PE partners and executives on SMBO's board (PE directors)}

Following on from the above arguments, management in SMBOs may have greater discretion to search for and pursue riskier growth opportunities, especially if hubris leads them to enter areas beyond their existing expertise, with adverse implications for performance. Alternatively, managers with a high level of ownership may be concerned with wealth preservation and reject risky projects with upside growth potential (Morck, Shleifer and Vishny, 1988). Therefore, to avoid managers taking actions against their interests, PE firms may insist on the presence of their PE partners and executives on SMBO boards to closely monitor strategic decisions.

PE directors may also help develop strategies to bring the SMBO to its next stage through exploiting entrepreneurial opportunities where further potential performance improvements from efficiency gains in the primary buyout are limited. In SMBOs where expansion is the main goal, new PE directors may bring new knowledge, skills, and resources and contribute to top management growth-oriented decision-making and strategy development (Bruining and Wright, 2002).

In addition, SMBOs may be driven by PE firms' overinvestment incentives and are more likely to be bad deals (Arcot et al., 2015) since selling PE firms would have an informational 
advantage and may try to sell underperforming portfolio companies. Buying PE firms under money-burning pressure would rely on due diligence conducted by the selling PE firms and make concessions. Under this scenario, the presence of PE directors, together with new appointments, are particularly important (Chahine and Goergen, 2011). Taking board seats helps PE directors understand the company better, allowing scrutiny of management's strategic initiatives, and reducing failure likelihood (McNulty and Pettigrew, 1999). Monitoring and advisory expertise of PE directors will likely focus on turning around primary buyouts that under-performed through active board involvement focused on closing poorly performing areas, improving operational efficiencies and reinvigorating areas with growth potential. Overall, the greater the need for turnaround and/or growth input the greater the expected presence of PE director appointments. Hence,

Hypothesis 1(a): The fraction of PE directors is positively related to post-SMBO performance in terms of profitability and growth.

Hypothesis 1(b) SMBOs' performance in the primary stage negatively moderates the positive relationships between the fraction of $P E$ directors and post-SMBO performance in terms of profitability and growth.

\subsection{Human capital of PE directors}

Depending on the importance of monitoring and advisory roles, PE directors need to possess different skills (Zahra et al., 2009). A mismatch between the skills of PE directors and the needs of the firm can create problems (Wright et al., 2001). We consider two distinct sources of human capital: work experience and education. VC research shows that directors from VC investors provide financial and operational knowledge and expertise to portfolio companies (Knockaert and Ucbasaran, 2013). Financial expertise is especially relevant to financial 
monitoring skills and cost-cutting. In SMBOs, performance improvement may come from finance PE directors closely monitoring the firm's ability to service the higher debt typical of SMBOs and through further cost-reductions not identified by management and previous PE directors.

However, tight financial control may constrain the flexibility needed for entrepreneurial growth (Wright et al., 2001). Rather, operational expertise may better provide advice about operational and managerial issues to help companies achieve organic growth. Some SMBOs may need support from operational PE directors in strengthening core products and markets. PE partners and executives may bring deep sectoral knowledge and experience of operational and managerial challenges, helping existing management in operational improvements to generate revenue growth.

The level of formal education is positively related to receptivity to innovation (Zona, Zattoni and Minnichilli, 2013). Although they will have gained some exposure to standard financial control techniques, high level business education is distinctive in providing understanding and influence over the administrative complexity and sophistication of organizations (Hambrick and Mason, 1984), as tools to address the uncertainty of companies and markets so as to identify and exploit growth opportunities that will enable the firm to achieve a strategic competitive advantage (Bertrand and Schoar, 2003). Highly educated managers are also prone to make more acquisitions than others (Palmer and Barber, 2001). Some SMBOs may need advice on plans to enter new markets, as well as to diversify the product and customer offerings via strategic acquisitions. Such decisions require expertise relating to competitive market dynamics, economies of scale and scope, etc. that are the foci of high level business education. PE directors with such education may be better at advising on 
operational and strategic decisions and in facilitating the right acquisitions to help growth.

The balance between board monitoring and advisory roles may need to change across different company life-cycle phases (Aguilera et al., 2008), with implications for the mix of board expertise. The move from primary to secondary management buyout represents such a life-cycle shift. Performance improvement in SMBOs may come from complementary resources and expertise provided by buying PE firms' directors compared to those of selling PE firms' directors. Selling PE directors focusing on efficiency improvement may only have financial expertise, while buying PE directors with operational expertise for revenue growth or high level business education resources for acquisitions may further enhance performance. Additionally, SMBOs growing to the next life stage may require different resources and capabilities for further growth. Selling PE directors may only be able to exploit the 'low hanging fruit' in terms of growth opportunities, while buying $\mathrm{PE}$ directors with more resources and high level expertise and capabilities can identify and exploit further growth opportunities. Hence,

Hypothesis 2a: SMBOs with PE directors with specific human capital in terms of previous work experience in finance will have better post-SMBO performance in terms of profitability. Hypothesis 2b: SMBOs with PE directors with specific human capital in terms of previous work experience in operations will have better post-SMBO performance in terms of growth. Hypothesis 2c: SMBOs with PE directors with specific human capital in terms of a high level of education in business (MBA) will have better post-SMBO performance in terms of growth. Hypothesis 3a: SMBOs with PE directors with complementary human capital to selling PE directors in terms of previous working experience in finance will have better post-SMBO performance in terms of profitability. 
Hypothesis 3b: SMBOs with PE directors with complementary human capital to selling PE directors in terms of previous working experience in operations will have better post-SMBO performance in terms of growth.

Hypothesis 3c: SMBOs with PE directors with complementary human capital to selling PE directors in terms of previous experience in terms of a high level of education in business (MBA) will have better post-SMBO performance in terms of growth.

\section{Data and methodology}

\subsection{Data and sample description}

The Centre for Management Buyout Research (CMBOR) database was used to identify UK SMBOs. PE backing, together with PE firms entry and exit dates, was obtained from Thomson One Banker and Zephyr. Accounting information was collected from FAME. We excluded companies from the finance sector due to their different accounting reporting.

To obtain data on board compositions from 3 years before to 5 years after SMBO transactions, changes in top management, and biographical information for each PE director, we combined sources including Amadeus, annual reports, Thomson One Banker, Zephyr, deal announcements, Bloomberg business week website (http://investing.businessweek.com), PE firms' websites, Linkedin, and Zoominfo. We obtained a final sample of $200 \mathrm{UK}$ SMBOs backed by PE firms in both primary and secondary stages during 2000-2015. Acharya et al (2013) use interview data related only to the leading PE executives in a sample of large and mid-cap deals, backed by large PE houses. We consider all PE executives on the board and both small and large deals. On average, we track 1.3 strictly PE-related individuals per deal which compares favorably to Acharya et al. (2013). The mean for "PE-network" directors per 
deal is 0.24 .

Figure 1 presents the yearly distributions of sample SMBOs by entry and exit. Popularity of SMBOs during the sample period with a sharp drop in the number of entries in 2008 , is consistent with other worldwide (Jenkinson and Sousa, 2015) and UK studies (Zhou, Jelic and Wright, 2014).

\section{Figure 1: Sample distribution across years}

This Figure shows the numbers of entry and exit of sample SMBOs across years. Cut-off point for exits was $30^{\text {th }}$ June 2015.

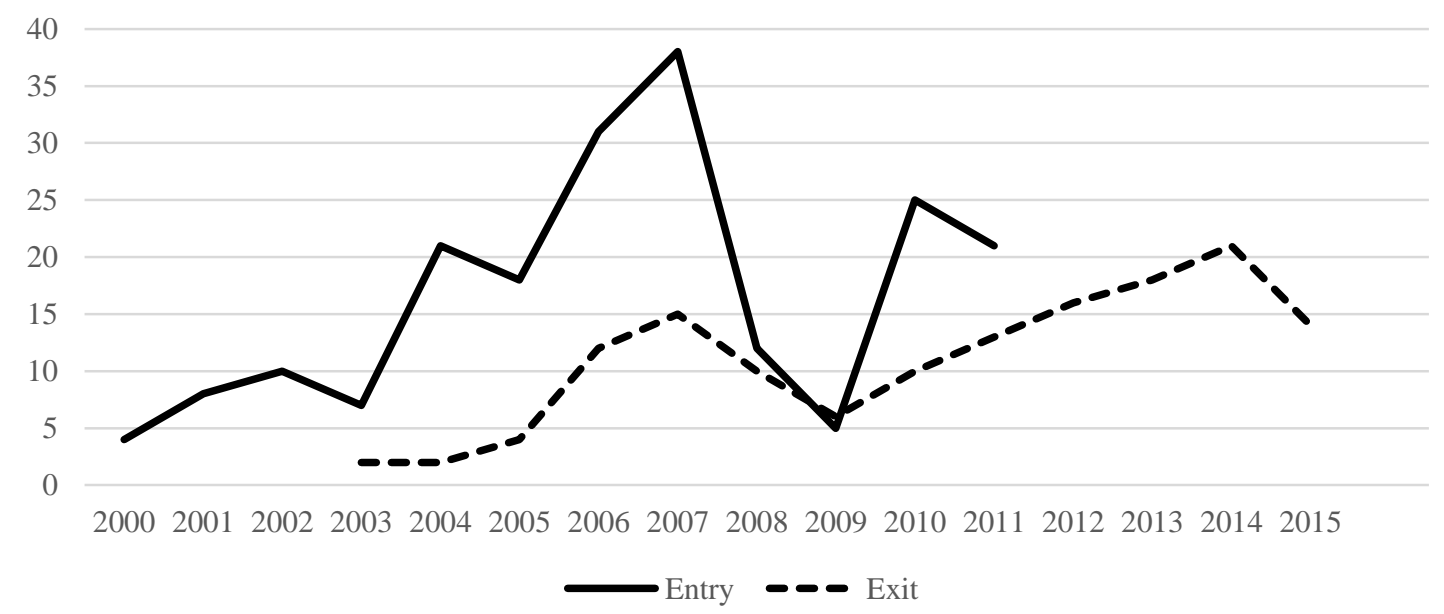

Consistent with Degeorge, Martin and Phalippou (2016) we find SMBOs are larger and more leveraged investments (see Table 1). Average (mean and median) for $S A L G$ and $E M P G$ are positive both in the primary and secondary buyout stages. Unreported results suggest that whilst profitability significantly improves during the primary phase (from Y-3 to Y-1) growth performance remains statistically unchanged. The difference in pre/post average (mean and median) unadjusted ratios is negative and statistically significant for $R O A$ and $E M P G$.

Table 1: Primary buyouts vs. SMBOs

\begin{tabular}{|l|l|l|l|l|l|l|}
\hline & \multicolumn{2}{|c|}{ Primary phase } & \multicolumn{2}{c|}{ SMBO } & \multicolumn{2}{c|}{ Difference } \\
\hline & Mean & Median & Mean & Median & T-test & MW test \\
\hline$T A$ & 53.250 & 26.909 & 73.736 & 39.542 & $20.487 * * *$ & $12.633^{* * *}$ \\
\hline
\end{tabular}




\begin{tabular}{|l|l|l|l|l|l|l|}
\hline GEAR & 124 & 63 & 134 & 70 & 10 & 7 \\
\hline$R O A$ & 6.7 & 7.6 & -4.8 & 1.9 & $-0.115^{* *}$ & $-0.057^{* * *}$ \\
\hline$R O S$ & 2.2 & 4.9 & -11.8 & 3.7 & -0.140 & -0.011 \\
\hline$S A L G$ & 4.5 & 5.9 & 1.0 & 2.6 & -0.035 & $-0.033^{* *}$ \\
\hline$E M P G$ & 7.0 & 5.3 & 2.2 & 2.0 & $-0.048 * * *$ & $-0.033^{* * *}$ \\
\hline
\end{tabular}

Notes: Primary phase includes a period from -3 to -1 years before SMBO transaction. SMBO includes a period from +1 to +5 years after SMBO transaction. TA total assets (in $£$ million). GEAR (\%) is sum of long term and short term debt divided by the total equity. ROA (\%) is company's earnings before interests and taxes (EBIT) scaled by the total assets in the same year. ROS $(\%)$ is company's earnings before interests and taxes (EBIT) scaled by the total sales in the same year. EMPG $(\%)$ is the difference between the company's end of year number of employees in year $\mathrm{t}$ and year $\mathrm{t}-1$, scaled by the average of number of employees in year $\mathrm{t}$ and $\mathrm{t}-1$. $S A L G(\%)$ is the difference between the company's sales in year $\mathrm{t}$ and year $\mathrm{t}-1$, scaled by the average of sales in year $\mathrm{t}$ and $\mathrm{t}-1$.

We rank PE firms on the basis of the reputation score established by Jelic (2011). Regarding PE firm reputation we find that sample SMBOs are predominantly backed by PE firms outside the top 10 (i.e. less reputed) (Table 2). This finding contradicts Degeorge, Martin and Phalippou (2016) but is consistent with Strömberg (2008), Harford and Kolasinski (2013) and Arcot et al. (2015). Arcot et al. (2015) suggest that less reputed PE firms may be under pressure to engage more in SMBOs to establish a track record.

Table 2: PE firm reputation

\begin{tabular}{|l|c|c|}
\hline & Primary phase & SMBO \\
\hline Top 10 PE firms & 61 & 23 \\
\hline Other PE firms & 139 & 177 \\
\hline
\end{tabular}

Notes: this table presents the numbers of sample SMBOs backed by Top 10 PE firms in primary phase and secondary stage, respectively.

Consistent with other studies (Lerner et al. 2002 as cited in Cornelli and Karakaş, 2013), we find that not all PE firms are represented on boards. Specifically, this was the case in 21 smaller SMBOs backed by large PE firms with many portfolio companies (e.g. 3i).

We classify sample buyouts into 8 broad industries, in line Gompers et al. (2008). Business Services $(37 \%)$ is the largest industry group, followed by Consumer $(30.5 \%)$ and Business and Industrial (17.5\%).

Table 3: Sample distribution across industries

\begin{tabular}{|l|c|c|}
\hline Industry & $\mathrm{N}$ & Percent \\
\hline
\end{tabular}




\begin{tabular}{|l|c|c|}
\hline 1. Internet \&Computers & 5 & 2.5 \\
\hline 2. Communications \& Electronics & 7 & 3.5 \\
\hline 3. Business \& Industrial & 35 & 17.5 \\
\hline 4. Consumer & 61 & 30.5 \\
\hline 5. Energy & 3 & 1.5 \\
\hline 6. Biotech and Healthcare & 11 & 5.5 \\
\hline 7. Business Services & 74 & 37 \\
\hline 8. All other & 4 & 2 \\
\hline Total sample & 200 & 100 \\
\hline
\end{tabular}

Results in Table 4 suggest significant differences in governance and human capital between sample buyouts in their primary and secondary phases. For example, PE firms engaged in SMBOs increase board size $(L N B S)$ and their representation on boards (PED). They also bring more experience-based expertise (Finance and Operation) together with experts with $M B A$ degrees.

Table 4: Changes in governance

\begin{tabular}{|l|c|c|c|c|c|c|}
\hline & \multicolumn{2}{|c|}{ Primary phase } & \multicolumn{2}{c|}{ SMBO } & \multicolumn{2}{c|}{ Difference } \\
\hline & Mean & Median & Mean & Median & T-test & MW test \\
\hline LNBS & 1.66 & 1.7 & 1.71 & 1.79 & $-0.05^{* * *}$ & $-0.09 * * *$ \\
\hline PED (\%) & 0.16 & 0.17 & 0.21 & 0.2 & $-0.05^{* * *}$ & $-0.03 * * *$ \\
\hline Finance(no.) & 0.61 & 0 & 0.88 & 1 & $-0.27 * * *$ & $-1 * * *$ \\
\hline Operation(no.) & 0.24 & 0 & 0.34 & 0 & $-0.10^{* * *}$ & $-0.00^{* * *}$ \\
\hline MBA(no.) & 0.16 & 0 & 0.24 & 0 & $-0.08^{* * *}$ & $-0.00^{* * *}$ \\
\hline
\end{tabular}

Notes: Primary phase includes a period from -3 to -1 years before SMBO transaction. SMBO includes a period from +1 to +5 years after SMBO transaction. All other variables defined in the paper.

\subsection{Performance, PE boards and human capital}

We use two sets of performance measures: profitability and growth. Profitability, measured by return on assets $(R O A)$ and return on sales $(R O S)$, has been widely used in the buyout literature to examine efficiency improvements associated with financial monitoring and agency costs reduction (Guo, Hotchkiss and Song, 2011). However, profitability cannot capture the entrepreneurial growth activities that lead to revenue growth and firm size growth. Hence, following previous literature (Meuleman et al., 2009; Cressy, Munari and Malipiero, 2007), we adopt two widely used growth ratios, employment growth (EMPG) and sales growth $(S A L G)$. 
We use the 'change' model of Barber and Lyon (1996) to measure abnormal performance ratios of profitability (AROA, AROS), employment growth $(A E M P G)$, and sales growth $(A S A L G)$. Thus, abnormal performance is the difference between actual and expected postSMBO performance. Expected performance is a company's median performance, during 3years before SMBO, adjusted for the performance change in a respective industry:

$$
A P_{i t}=P_{i t}-E\left(P_{i t}\right)
$$

where, $P_{i t}$ is the actual performance ratio of company $\mathrm{i}$ in year $\mathrm{t}$ during post-event (years, +1 to +5$)$ periods ; $E\left(P_{i t}\right)$ is the expected performance of company $\mathrm{i}$ in year $\mathrm{t}$; and $A P_{i t}$ is the abnormal performance for the performance ratio (AROA, AROS, ASALEG, AEMPG). We compare performance in each year post event with pre-SMBO performance, for a period up to five years. We exclude the event year 0 , as it includes both pre-and post- event operations which are difficult to distinguish.

Our expected performance model also follows Barber and Lyon (1996):

$$
E\left(P_{i t}\right)=P_{i, t-k}+\Delta P I_{i t}
$$

Where $P_{i, t-k}$ is pre-SMBO performance of company i. $P I_{i t}$ is defined as the industry performance for company $\mathrm{i}$ in period t. $\Delta P I_{i t}$ is the difference between industry control group's performance in period $\mathrm{t}$ and the industry's median pre-SMBO performance. The industry performance was calculated based on accounting data on UK private companies. The relevant accounting data of all UK private companies $(22,163)$ was collected from FAME and represents our industry benchmark. We then classified companies into 8 industries and 
calculated the median value as the industry performance $\left(P I_{i t}\right)$.

Involvement of PE partners and executives is measured as the percentage of PE directors on the board $(P E D)$. Our human capital variables are measured based on biographical information. As Degeorge, Martin and Phalippou (2016) and Acharya et al. (2013), we identify each PE director for whether s/he had worked in finance, accounting, or banking (financial experience) or whether s/he had worked in industry or management consulting (operational experience) before joining PE industry. For high level business education, we identify each PE director for whether s/he holds an MBA. Following previous literature (Tian, Haleblian and Rajagopalan, 2011), human capital is measured as a categorical variable equaling 1 if one or more PE directors poses relevant experience (Financial/Operational) or MBA degree $(M B A), 0$ otherwise.

To capture complementarity skills and their potential impact on value creation, we assign categorical variables to all cases where a buying PE firm added particular new expertise to

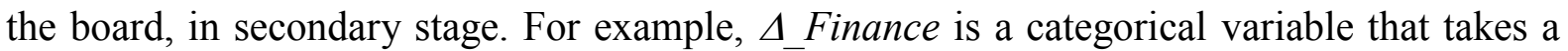
value of 1 if the buying PE firm appointed at least one PE director with financial experience to the board without financially experienced PE director(s) in primary stage. Similarly, $\triangle \_$Operation and $\triangle \_M B A$ depict complementarity skills related to operational experience and MBA degree respectively.

As aforementioned, increased managerial ownership and loosened PE firm control in the second round may lead to management entrenchment and hence may worsen post-SMBO performance. We, therefore, control for management ownership (MGTSHARE). Further, larger companies may be more profitable than smaller ones, while smaller ones may have 
more opportunities to grow. We control for size (LNSIZE) and industry adjusted profitability prior to the SMBO (Pre_ROA). Time was controlled by yearly categorical variables and a categorical variable for the 2008-2010 financial crisis (Crisis). We control for gearing (GEAR) and time to exit SMBOs (LNDURATION). High gearing can multiple effects of good/bad performance whilst duration controls for the fact that some of the improvements tend to be more time consuming. Finally, we control for the following board-related variables identified in previous literature: Board size (LNBS) (O’Connell and Cramer, 2010); independent outside directors (Ind_outsider) (Lerner, 1995); inside directors (Insider) (Masulis and Mobbs, 2011); and replacement of top managers (MGTCHAN) (Gong and Wu, 2011). Definitions of variables are presented in Appendix 1.

\subsection{Estimation method}

PE firms do not randomly choose buyouts in which to invest but conduct due diligence to select companies with certain characteristics leading to a greater probability of success in the SMBO phase. To address issues related to potential selection bias, we employ a Heckman (1979) two-step model. In the first step, we estimate a Probit regression with a robust variance estimate for the probability of a new PE firm's involvement in a sample SMBO. The dependent variable is a categorical variable equal to 1 if the SMBO is PE-backed and 0 otherwise. For the Probit model we therefore use a large sample of 351 PE-backed and nonPE backed SMBOs, during the period 2000-2011. The control sample includes deals from 8 different industries. Business Services and Consumers are the most important sources of the deals. The control sample is dominated by MBOs (59\%). The majority (72\%) of the control sample deals are PE-backed.

The following variables are identified as important determinants of PE firm's investments in 
previous literature: buyout size (Strömberg, 2008); pre-event performance (Bienz, 2004); previous PE backing (Acort et al., 2015); buyout type (Wright et al., 2001); industry (Bayar and Chemmanur, 2006). We therefore hypothesize that PE firm choice to invest in an SMBO is associated with SMBO size (LNSIZE), pre-SMBO performance (Pre_ROA), buyout type (BUYIN), previous PE backing (Pre_PE) and target company industry (BSERVICES).

Estimated probability of a PE firm's investment in an SMBO (Lambda) is then included in the second stage to correct for selection bias. In the second step, we use random-effects Generalized Least Squares (GLS) regression with abnormal performance ratios of profitability $(A R O A, A R O S)$, productivity $(A S A L E M P)$, employment growth $(A E M P G)$, and sales growth $(A S A L G)$ as dependent variables. To examine whether previous performance moderates the impact of $\mathrm{PE}$ directors on post-SMBO performance, we interact the fraction of PE directors $(P E D)$ with a categorical variable of poor performer (Poor_ROA). Poor_ROA equals 1 if Pre-ROA is below than its median value and 0 otherwise. Our preference for GLS over OLS is motivated by the panel method utilizing data from the entire post-SMBO period while OLS relies on data from only one post-SMBO year. Additionally, panel data estimation takes into account the effects of estimation error due to the correlation of the residuals across firms (Fama and French, 2001). Hausman tests for all models suggest that our dataset is suitable for random-effects models instead of fixed-effects models.

\section{Empirical results}

\subsection{Descriptive statistics}

Descriptive statistics and correlations are presented in Table 5. Consistent with previous studies, the negative mean values of $A R O A, A E M P G$, and $A S A L G$ demonstrate overall underperformance of SMBOs. As expected, average gearing ratio of sample buyouts is high 
(134\%). On average, managers hold about $38 \%$ of shares in SMBOs. It takes, on average, 4 years for PE firms to exit SMBOs. On average, boards consist of 6 (5.52) directors. PE directors with financial experience were most represented on the boards - $60 \%$ have one or more PE directors with financial experience. This is considerably higher than related percentages for PE directors with operational experience $(28 \%)$ and MBA degree $(21 \%)$. About one quarter of sample buying PE firms added complementary financial skills to the boards. Similarly, new appointments of PE directors with operational experience and MBA degree were made in $22 \%$ and $19 \%$ cases, respectively. Ind_outsiders constitute $53 \%$ of all outside directors. Active CEOs constitute $34.7 \%$ of all Ind_outsiders. The correlation coefficient between active CEO and Ind_outsiders is 0.61 which is higher than correlation of 0.13 reported in de Villiers et al. (2011).

\subsection{Regression results}

Results of Probit (Panel A) and GLS estimations (Panel B) are presented in Table 6. As expected, buyins, buyouts with PE backing in the primary stage, and larger buyouts are more likely to receive PE investments (Panel A). Marginal effects (reported in brackets) suggest that previous PE involvement increases likelihood of a new PE backing by $25.2 \%$. Similarly, buy-ins are $27.5 \%$ more likely to receive PE backing compared to their buy-out counterparts. Panel B presents the impact of PE directors' $(P E D)$ on post-SMBO performance, up to five years after SMBO. Coefficients for $P E D$ are positive and statistically significant in models for growth: for example, AEMPG 5 (coefficient=0.398, $\mathrm{p}<0.06$ ) and $A S A L G 7$ (coefficient $=0.724, \mathrm{p}<0.01$ ). In models for profitability, evidence is mixed. The coefficient for $P E D$ is statistically significant (coefficient $=0.151, \mathrm{p}<0.03$ ) in model 2 but not in models 1,3 , and 4. Economically, the variation in the magnitude of the coefficient suggests that PE directors matter most for employment growth $(A E M P G)$ and sales growth $(A S A L G)$. For 
example, one standard deviation change in $P E D$ results in $6 \%$ employment growth (model 5) and $11.6 \%$ growth in sales (model 7). Thus, a higher percentage of PE directors on the board leads to better growth in employment and sales. Hence, hypothesis (1a) is supported in terms of growth. 
Table 5: Sample descriptive statistics and correlation matrix

\begin{tabular}{|c|c|c|c|c|c|c|c|c|c|c|c|c|c|c|c|c|c|c|c|c|c|c|}
\hline Variable & Mean & S.D. & 1 & 2 & 3 & 4 & 5 & 6 & 7 & 8 & 9 & 10 & 11 & 12 & 13 & 14 & 15 & 16 & 17 & 18 & 19 & 20 \\
\hline $1 \mathrm{AROA}$ & -0.06 & 0.18 & 1.00 & & & & & & & & & & & & & & & & & & & \\
\hline $2 A R O S$ & 0.00 & 0.19 & 0.52 & 1.00 & & & & & & & & & & & & & & & & & & \\
\hline $3 A E M P G$ & -0.05 & 0.26 & 0.19 & 0.17 & 1.00 & & & & & & & & & & & & & & & & & \\
\hline $4 A S A L G$ & -0.08 & 0.34 & 0.21 & 0.19 & 0.55 & 1.00 & & & & & & & & & & & & & & & & \\
\hline 5 PED & 0.21 & 0.16 & 0.07 & 0.01 & 0.08 & -0.01 & 1.00 & & & & & & & & & & & & & & & \\
\hline 6 Finance & 0.60 & 0.49 & 0.11 & 0.12 & 0.06 & -0.04 & 0.59 & 1.00 & & & & & & & & & & & & & & \\
\hline 7 Operation & 0.28 & 0.45 & 0.03 & -0.03 & -0.04 & -0.08 & 0.39 & 0.16 & 1.00 & & & & & & & & & & & & & \\
\hline $8 M B A$ & 0.21 & 0.41 & 0.05 & 0.02 & 0.17 & 0.10 & 0.32 & 0.28 & 0.40 & 1.00 & & & & & & & & & & & & \\
\hline 9 __Operation & 0.22 & 0.42 & 0.08 & 0.02 & 0.02 & -0.01 & 0.28 & 0.07 & 0.76 & 0.30 & 1.00 & & & & & & & & & & & \\
\hline 10 __Finance & 0.26 & 0.44 & 0.00 & 0.04 & -0.04 & -0.11 & 0.16 & 0.41 & 0.00 & 0.11 & 0.00 & 1.00 & & & & & & & & & & \\
\hline $11 \triangle_{-} M B A$ & 0.19 & 0.39 & 0.06 & 0.07 & 0.15 & 0.07 & 0.28 & 0.23 & 0.34 & 0.82 & 0.33 & 0.19 & 1.00 & & & & & & & & & \\
\hline $12 L N B S$ & 1.71 & 0.34 & 0.10 & 0.08 & -0.01 & -0.02 & 0.31 & 0.50 & 0.24 & 0.25 & 0.17 & 0.17 & 0.17 & 1.00 & & & & & & & & \\
\hline 13 Ind_outsiders & 0.06 & 0.10 & 0.00 & -0.01 & 0.15 & 0.08 & -0.17 & -0.07 & -0.12 & -0.08 & -0.11 & -0.05 & -0.03 & 0.02 & 1.00 & & & & & & & \\
\hline 14 MGTCHAN & 0.48 & 0.50 & -0.09 & 0.03 & -0.08 & 0.04 & 0.00 & 0.02 & 0.08 & 0.02 & 0.00 & -0.04 & -0.02 & -0.01 & -0.06 & 1.00 & & & & & & \\
\hline 15 Insider & 0.66 & 0.19 & -0.08 & -0.05 & -0.07 & 0.06 & -0.69 & -0.45 & -0.18 & -0.15 & -0.11 & -0.13 & -0.12 & -0.24 & -0.24 & -0.02 & 1.00 & & & & & \\
\hline 16 MGTSHARE & 0.38 & 0.28 & 0.13 & 0.07 & -0.02 & 0.08 & -0.21 & -0.19 & -0.11 & -0.25 & -0.03 & -0.05 & -0.23 & -0.05 & -0.03 & -0.05 & 0.17 & 1.00 & & & & \\
\hline 17 GEAR & 1.34 & 1.74 & -0.11 & -0.13 & -0.10 & -0.12 & -0.05 & -0.05 & -0.06 & -0.02 & -0.05 & -0.01 & 0.00 & 0.04 & -0.06 & 0.01 & 0.07 & -0.07 & 1.00 & & & \\
\hline 18 LNDURATION & 4.03 & 0.54 & -0.08 & 0.01 & 0.03 & 0.04 & -0.12 & -0.08 & -0.12 & -0.05 & -0.08 & -0.07 & -0.09 & -0.12 & 0.02 & 0.14 & 0.10 & 0.10 & 0.04 & 1.00 & & \\
\hline 19 LNSIZE & 3.65 & 1.57 & -0.11 & -0.01 & 0.03 & -0.05 & 0.28 & 0.23 & 0.04 & 0.20 & 0.04 & -0.02 & 0.15 & 0.23 & -0.05 & 0.03 & -0.12 & -0.39 & 0.00 & 0.02 & 1.00 & \\
\hline 20 Crisis & 0.50 & 0.50 & 0.04 & 0.05 & -0.05 & 0.02 & -0.01 & 0.01 & -0.12 & 0.03 & -0.10 & -0.01 & 0.00 & -0.07 & -0.17 & -0.01 & 0.05 & 0.04 & -0.02 & 0.24 & 0.02 & 1.00 \\
\hline 21 Pre_ROA & 0.10 & 0.42 & -0.25 & -0.18 & -0.12 & -0.07 & 0.01 & 0.03 & -0.09 & 0.05 & -0.06 & 0.05 & 0.06 & -0.04 & -0.07 & 0.05 & 0.07 & 0.10 & -0.24 & 0.08 & 0.17 & 0.06 \\
\hline
\end{tabular}


Table 6: Effects of PE directors on post-SMBO performance

\begin{tabular}{|l|l|}
\hline \multicolumn{2}{|c|}{ Panel A: 1st stage } \\
\hline \multicolumn{2}{|c|}{ Probit model } \\
\hline Pre_ROA & $0.617(0.166)$ \\
\hline BSERVICES & $-0.049(-0.013)$ \\
\hline LNSIZE & $0.517(0.139)^{* * *}$ \\
\hline BUYIN & $1.489(0.275)^{* * *}$ \\
\hline Pre PE & $0.823(0.252)^{* * *}$ \\
\hline Intercept & $-1.580(-0.426)^{* * *}$ \\
\hline Log lik. & -137.372 \\
\hline PseudoR $(\%)$ & 37.5 \\
\hline Chi2 & $109.214^{* * *}$ \\
\hline$N$ & 351 \\
\hline
\end{tabular}




\begin{tabular}{|c|c|c|c|c|c|c|c|c|}
\hline Panel B: $2^{\text {nd }}$ & \multicolumn{2}{|c|}{$A R O A$} & \multicolumn{2}{|c|}{ AROS } & \multicolumn{2}{|c|}{$A E M P G$} & \multicolumn{2}{|c|}{$A S A L G$} \\
\hline GLS model & 1 & 2 & 3 & 4 & 5 & 6 & 7 & 8 \\
\hline$P E D$ & $0.069(0.071)$ & $0.151 * *(0.07)$ & $0.021(0.113)$ & $0.093(0.094)$ & $0.398 *(0.209)$ & $0.575 *(0.303)$ & $0.724 * * *(0.267)$ & $0.904 * * *(0.256)$ \\
\hline$P E D^{*}$ & & $-0.310 * * *(0.093)$ & & $-0.319(0.273)$ & & $-0.361 *(0.214)$ & & $-0.719 * *(0.296)$ \\
\hline$L N B S$ & $0.024(0.029)$ & $0.009(0.028)$ & $0.016(0.052)$ & $-0.001(0.05)$ & $0.013(0.040)$ & $0.004(0.050)$ & $0.021(0.064)$ & $0.019(0.060)$ \\
\hline Ind outsiders & $-0.011(0.104)$ & $-0.029(0.099)$ & $0.032(0.11)$ & $-0.005(0.107)$ & $0.445 * *(0.216)$ & $0.666^{* *}(0.301)$ & $1.068 * * *(0.307)$ & $1.026 * * *(0.274)$ \\
\hline$M G T C H A N$ & $-0.007(0.021)$ & $-0.009(0.02)$ & $0.038(0.038)$ & $0.038(0.037)$ & $-0.036(0.03)$ & $-0.048(0.036)$ & $0.03(0.043)$ & $0.029(0.039)$ \\
\hline Insiders & $-0.038(0.071)$ & $-0.037(0.065)$ & $0.010(0.100)$ & $-0.003(0.088)$ & $0.256(0.171)$ & $0.322(0.24)$ & $0.660 * * *(0.245)$ & $0.625 * * *(0.230)$ \\
\hline MGTSHARE & $0.031(0.046)$ & $0.028(0.041)$ & $0.019(0.05)$ & $0.008(0.046)$ & $0.035(0.061)$ & $0.009(0.071)$ & \begin{tabular}{|l|}
$0.052(0.08)$ \\
\end{tabular} & $0.056(0.072)$ \\
\hline GEAR & $-0.025 * * *(0.006)$ & $-0.027 * * *(0.006)$ & $-0.024 * * *(0.008)$ & $-0.025 * * *(0.008)$ & $-0.009(0.01)$ & $-0.014(0.013)$ & $-0.024(0.018)$ & $-0.015(0.014)$ \\
\hline LNDURATION & $-0.035(0.022)$ & $-0.028(0.02)$ & $-0.003(0.042)$ & $0.004(0.042)$ & $-0.01(0.039)$ & $0.002(0.046)$ & $-0.006(0.054)$ & $-0.029(0.049)$ \\
\hline LNSIZE & $-0.002(0.014)$ & $-0.011(0.013)$ & $-0.034(0.024)$ & $-0.041 *(0.025)$ & $0.009(0.019)$ & $0.002(0.021)$ & $0.019(0.028)$ & $0.013(0.026)$ \\
\hline Crisis & $-0.011(0.012)$ & $-0.011(0.012)$ & $0.002(0.016)$ & $0.003(0.016)$ & $-0.079 * *(0.033)$ & $-0.092 * *(0.038)$ & $-0.096 *(0.052)$ & $-0.055(0.040)$ \\
\hline Pre ROA & $-0.057(0.048)$ & & $-0.044(0.053)$ & & $-0.210 * * *(0.065)$ & & $-0.017(0.032)$ & \\
\hline Poor $\mathrm{ROA}$ & & $0.184 * * *(0.031)$ & & $0.180 * * *(0.067)$ & & $0.102 *(0.057)$ & & $0.161 * *(0.075)$ \\
\hline$L a m b d a$ & $0.005(0.059)$ & $-0.04(0.057)$ & $-0.205 * *(0.104)$ & $-0.232 * *(0.104)$ & $0.045(0.090)$ & $0.010(0.104)$ & $0.256 * *(0.113)$ & $0.210 *(0.107)$ \\
\hline Intercept & $-0.105(0.282)$ & $-0.155(0.261)$ & $0.142(0.242)$ & $0.074(0.234)$ & $-0.154(0.268)$ & $-0.251(0.321)$ & $-1.020 * * *(0.356)$ & $-0.901 * * *(0.334)$ \\
\hline Years & Yes & Yes & Yes & Yes & Yes & Yes & Yes & Yes \\
\hline$R^{2}(\%)$ & 9.04 & 19.8 & 7.87 & 12.17 & 15.7 & 14.36 & 14.94 & 18.87 \\
\hline Chi2 & $42.425 * * *$ & $73.725 * * *$ & $35.681 * *$ & $44.554 * * *$ & $190.163 * * *$ & $167.260 * * *$ & $93.103 * * *$ & $92.477 * * *$ \\
\hline$N$ & 450 & 450 & 402 & 402 & 335 & 335 & 377 & 377 \\
\hline
\end{tabular}

Notes: This table reports the results of the panel regression corrected for sample selection bias for the effect of PE directors on post-SMBO performance, up to five years after SMBO transaction. The Probit regression (Panel A) with robust variance estimate is for the probability of receiving PE backing by the sample SMBOs. This model converged after three iterations. Marginal effects in Panel A, reported in (parentheses). The panel regression (Panel B) is for the influence of PE directors on post-SMBO performance. The dependent variables (AROA, AROS, $A E M P G$, and $A S A L G$ ) are estimated as industry-adjusted abnormal performance measures. Lambda is the fitted probability of receiving PE backing, estimated from the Probit regression model. All the results are based on $99 \%$ winsorized data. All parameters of panel regressions are estimated by a GLS random-effects model with robust standard error, omitted collinear covariates, and cluster by firm. Entry year dummies are included. P-values for the Wald test are for probability $>\mathrm{Chi}^{2} . N$ in Panel A reports the total number of SMBOs including pure and sample SMBOs. $N$ in Panel B reports the number of firm-year observations in the panel regression model. ${ }^{*} \mathrm{p}<10 \% ; * * \mathrm{p}<5 \%$, $* * * \mathrm{p}<1 \%$. Robust standard errors of regressions are reported in brackets. The variables

are defined 
Interaction term coefficients $\left(P E D^{*} P o o r_{-} R O A\right)$ are negative and statistically significant in the models for $A R O A 2$ (coefficient $=-0.310, \mathrm{p}<0.01), A E M P G 6$ (coefficient $=-0.361, \mathrm{p}<0.10)$, and $A S A L G 8$ (coefficient=-0.719, $<<0.02$ ). The significantly negative coefficients imply poorly performing buyouts require more PE expertise to improve growth, measured by $A E M P G$ and $A S A L G$. This supports hypothesis 1(b).

Considering the impact of the human capital resources of PE directors on post-SMBO performance, Table 7 shows coefficients for financial experience (Finance) are positive and statistically significant in models for profitability: $A R O A 1$ (coefficient $=0.058, \mathrm{p}<0.02$ ) and AROS 3 (coefficient $=0.096, \mathrm{p}<0.05$ ). Thus, presence of PE directors with financial experience has a positive effect on post-SMBO profitability, supporting H2a. There is no statistically significant impact of operational background (Operation) on post-SMBO performance; hence $\mathrm{H} 2 \mathrm{~b}$ is not supported. Coefficients for presence of PE directors with an MBA $(M B A)$ are positive and statistically significant in models for growth: AEMPG 5 (coefficient=0.117, $\mathrm{p}<0.03$ ) and $A S A L G 7$ (coefficient $=0.188, \mathrm{p}<0.01$ ), supporting our expectations of the impact of high level business education on post-SMBO growth ratios. One standard deviation change in Finance increases $A R O A(A R O S)$ by $2.8 \%(4.7 \%)$. One standard deviation change in $M B A$ results in about a $4.8 \%$ increase in $A E M P G$ and $7.7 \%$ increase in $A S A L G$. As to complementary human capital, the results show that one standard deviation change in $\triangle{ }_{-} M B A$ increases $A R O A, A R O S, A E M P G$, and $A S A L G$ by $2 \%, 3.5 \%, 4.2 \%$, and $5.6 \%$, respectively. Hence, our results provide mixed support for hypothesis $2 \mathrm{c}$. 
Table 7: Effects of the human capital of PE directors on post-SMBO performance

\begin{tabular}{|c|c|c|c|c|c|c|c|c|}
\hline \multirow[t]{2}{*}{ GLS model } & \multicolumn{2}{|c|}{$A R O A$} & \multicolumn{2}{|c|}{ AROS } & \multicolumn{2}{|c|}{$A E M P G$} & \multicolumn{2}{|c|}{$A S A L G$} \\
\hline & 1 & 2 & 3 & 4 & 5 & 6 & 7 & 8 \\
\hline Finance & $0.058^{* *}(0.023)$ & & $0.096 * *(0.047)$ & & $0.072(0.071)$ & & $0.000(0.081)$ & \\
\hline Operation & $0.001(0.019)$ & & $0.025(0.03)$ & & $-0.018(0.044)$ & & $-0.059(0.058)$ & \\
\hline$M B A$ & $-0.002(0.026)$ & & $-0.048(0.064)$ & & $0.117 * *(0.052)$ & & $0.188 * * *(0.069)$ & \\
\hline$\Delta$ Finance & & $0.003(0.021)$ & & $-0.026(0.033)$ & & $-0.038(0.043)$ & & $-0.070(0.052)$ \\
\hline$\Delta$ Operation & & $0.037 *(0.020)$ & & $0.034(0.03)$ & & $-0.009(0.051)$ & & $0.012(0.049)$ \\
\hline$\triangle M B A$ & & $0.050 *(0.026)$ & & $0.089 *(0.052)$ & & $0.108 *(0.063)$ & & $0.144 * *(0.071)$ \\
\hline$L N B S$ & $0.002(0.032)$ & $0.020(0.029)$ & $-0.016(0.064)$ & $0.014(0.053)$ & $-0.054(0.055)$ & $0.010(0.055)$ & $-0.006(0.062)$ & $0.026(0.068)$ \\
\hline Ind outsiders & $-0.019(0.09)$ & $-0.013(0.088)$ & $0.052(0.097)$ & $0.048(0.098)$ & $0.435 *(0.235)$ & $0.341(0.219)$ & $0.679 * * *(0.252)$ & $0.645 * * *(0.246)$ \\
\hline$M G T C H A N$ & $-0.01(0.021)$ & $-0.005(0.021)$ & $0.030(0.038)$ & $0.043(0.039)$ & $-0.046(0.034)$ & $-0.045(0.034)$ & $0.035(0.045)$ & $0.027(0.043)$ \\
\hline Insiders & $-0.036(0.057)$ & $-0.064(0.048)$ & $0.064(0.088)$ & $0.004(0.093)$ & $0.097(0.139)$ & $0.004(0.105)$ & $0.232(0.180)$ & $0.201(0.140)$ \\
\hline MGTSHARE & $0.040(0.046)$ & $0.042(0.048)$ & $0.025(0.052)$ & $0.037(0.052)$ & $0.066(0.07)$ & $0.025(0.067)$ & $0.082(0.082)$ & $0.073(0.079)$ \\
\hline GEAR & $-0.024 * * *(0.006)$ & $-0.025 * * *(0.006)$ & $-0.023 * * *(0.008)$ & $-0.024 * * *(0.008)$ & $-0.014(0.013)$ & $-0.015(0.013)$ & $-0.022(0.018)$ & $-0.025(0.018)$ \\
\hline LNDURATION & $-0.032(0.022)$ & $-0.038 *(0.020)$ & $-0.003(0.044)$ & $-0.006(0.04)$ & $0.011(0.043)$ & $0.021(0.043)$ & $-0.002(0.051)$ & $0.004(0.051)$ \\
\hline LNSIZE & $0.002(0.015)$ & $0.000(0.003)$ & $-0.025(0.025)$ & $-0.035(0.024)$ & $0.016(0.019)$ & $0.008(0.020)$ & $0.019(0.030)$ & $0.020(0.030)$ \\
\hline Crisis & $-0.010(0.012)$ & $-0.012(0.012)$ & $0.005(0.014)$ & $0.001(0.024)$ & $-0.098 * *(0.046)$ & $-0.107 * *(0.050)$ & $-0.110 *(0.061)$ & $-0.112 *(0.061)$ \\
\hline Pre ROA & $-0.057(0.047)$ & $-0.065(0.043)$ & $-0.045(0.057)$ & $-0.060(0.049)$ & $-0.146 * *(0.068)$ & $-0.142 * *(0.069)$ & $-0.017(0.029)$ & $-0.022(0.027)$ \\
\hline Lambda & $0.030(0.06)$ & $0.015(0.061)$ & $-0.155(0.109)$ & $-0.201 * *(0.101)$ & $0.039(0.103)$ & $-0.001(0.167)$ & $0.194(0.129)$ & $0.197(0.123)$ \\
\hline Intercept & $-0.134(0.273)$ & $-0.070(0.281)$ & $0.039(0.225)$ & $0.178(0.221)$ & $-0.044(0.274)$ & $-0.008(0.242)$ & $-0.538(0.344)$ & $-0.573 *(0.315)$ \\
\hline Years & Yes & Yes & Yes & Yes & Yes & Yes & Yes & Yes \\
\hline$R^{2}(\%)$ & 11.11 & 11.48 & 7.85 & 9.67 & 16.16 & 14.99 & 16.36 & 14.93 \\
\hline Chi2 & $63.006^{* * *}$ & $44.647 * * *$ & $39.552 * *$ & $39.119 * *$ & $177.870 * * *$ & $164.792 * * *$ & $63.773 * * *$ & $68.628 * * *$ \\
\hline$N$ & 450 & 450 & 402 & 402 & 335 & 335 & 377 & 377 \\
\hline
\end{tabular}

Notes: This table reports the results of the panel regression corrected for sample selection bias for the effect of human capital of PE directors on post-SMBO performance, up to five years after SMBO transaction. The dependent variables ( $A R O A, A R O S, A E M P G$, and $A S A L G$ ) are estimated as industry-adjusted abnormal performance measures. Lambda is the fitted probability of receiving PE backing, estimated from the Probit regression model in Panel A of Table 6. Model 1,3,5,7 report the results of the impact of human capital resources of PE directors on post-SMBO performance. Model 2,4,6,8 report the results of the effect of complementary human capital resources between the buying and selling PE firms on performance. All the results are based on $99 \%$ winsorized data. All parameters of panel regressions are estimated by a GLS random-effects model with robust standard error, omitted collinear covariates, and cluster by firm. Entry year dummies are included. P-values for the Wald test are for probability $>$ Chi ${ }^{2} . N$ reports the number of firm-year observations in the panel regression model. $* \mathrm{p}<10 \%$; $* * \mathrm{p}<5 \%, * * * \mathrm{p}<1 \%$.

Robust standard errors of regressions are reported in brackets. All variables are defined in Appendix 1.


Models 2, 4, 6, and 8 of Table 3 present results of the effect of complementary human capital resources between the buying and selling PE firms on performance. Coefficients for $\Delta$ _Finance are not statistically significant, indicating that $\mathrm{H} 3 \mathrm{a}$ is not supported. $\Delta$ _Operation is weakly positively associated with $A R O A 2$ (coefficient $=0.037, \mathrm{p}<0.07$ ), implying that incoming PE directors with complementary human capital in terms of operational experience improve profitability measured by $A R O A$, and providing some support for $\mathrm{H} 3 \mathrm{~b}$. We also find that coefficients for complementary human capital in terms of high level business education $\left(\triangle{ }_{-} M B A\right)$ are weakly positive and statistically significant in models for AROA 2 (coefficient $=0.050, \quad \mathrm{p}<0.06), \quad$ AROS $4 \quad$ (coefficient $=0.089, \quad \mathrm{p}<0.09), \quad A E M P G \quad 6$ (coefficient=0.108, $<<0.09$ ), and $A S A L G 8$ (coefficient=0.144, $<<0.05)$. These results support our previous findings and imply positive effects of high level business education on postSMBO growth performance. These findings provide support for hypothesis $3 \mathrm{c}$ in terms of high level business education.

These results are consistent with the summary statistics suggesting that PE directors with financial experience were most represented on boards followed by directors with operational experience and MBA degree. As expected, complementarity works better in deals where target buyouts lack a particular expertise (i.e. $M B A$ ). The $\mathrm{R}^{2} \mathrm{~s}$ of models involving growth ratios are generally higher than those of the models of profitability, indicating that the board relevant variables exhibit higher explanatory power in growth models.

Regarding control variables, we find that independent outsiders (Ind_outsiders) are significantly associated with growth ratios, suggesting that independent outside directors facilitate exploiting the growth opportunities. Ind_outsiders are active CEOs of other firms and other experts such as: consultants, businessmen, and university professors. They possess 
considerable experience-based human capital and thus provide an important advisory role. Our results (Tables 6 and 7) thus provide further evidence for the boards' advisory role. Our results are in line with de Villiers, Naiker and van Staden (2011) who report an important advisory role of active CEOs on boards and their positive association with performance. Consistent with Cornelli and Karakaş (2013), CEO replacements are not associated with performance improvements. As expected, the recent financial crisis is negatively associated with employment growth and sales growth.

\section{Robustness checks}

\subsection{Alternative proxies}

PE firms' decisions to appoint PE directors onto boards may be affected by PE firms' ability to identify good deals (Chahine and Goergen, 2011). Highly reputable PE firms are also more likely to identify good deals with less need to appoint PE directors. Syndicated deals and deals where top managers were replaced also require fewer appointments on boards. We also examine links between PE ownership and number of PE directors on the board, thus creating possibility that our results may be attributed to increasing PE ownership rather than involvement of PEDS. Hence, we re-estimate our Probit model with the above mentioned determinants affecting need for PE directors and re-run all GLS models with new Lambdas. Unreported results are economically and statistically consistent with the results reported in Tables 6 and 7.

Johnson, Schnatterly and Hill (2013) point out the sensitivity of results to how human capital variables are measured. We therefore conduct robustness checks with two alternative (continues) measures: the percentage and the number of PE directors with financial experience, operational experience and MBA degree. Unreported results with two alternative 
variables are economically and statistically consistent with our reported results for models using categorical variable for the human capital.

We also checked for robustness by considering a more inclusive definition of $P E D$ which includes experts not on PE firms' payroll. Those experts are however connected to PE firms and are proposed to portfolio companies by the PE firms. Unreported results are in line with results in Tables 6 and 7. Finally our results remain robust to use of $P E D$ as a categorical instead of $P E D$ as a continuous variable.

\subsection{Different types of PE firms}

Degeorge, Martin and Phalippou (2016) distinguish between PE firms with a margin focus (focused on increasing profits) and those with a growth focus (focused on increasing revenues). We therefore test for the possibility that results could be driven by type of investors rather than PED and their human capital. We distinguish between PE firms with a margin focus (Margin) and those with a growth focus (Growth). We control for the possibility that a PE firm with a growth focus might improve performance of a portfolio firm that has so far been sponsored by a PE firm with a margin focus (and vice versa) (Margin*Growth in Table 8; Panel A). The results (Panel A) show that the coefficients for $P E D$ remain positive and statistically significant in the models for $A E M P G$ and $A S A L G$. The coefficients for PED*Poor_ROA (see Panel A) are negative but not statistically significant.

We also create further categorical variables for a buyer with margin focus and growth focus and interact them with relevant variables for skills and complementary human capital (Table 8; Panels B and C). Overall operational skills and MBA education tend to work better in PE firms with Growth. The positive and statistically significant coefficient for Finance*BMargin in the model for AROS (model 4 in Panel B) provides some evidence that finance expertise 
contributes to improvements in profitability. The results in models for the complementarity between two PE firms in relation to education (i.e. $\triangle M B A$ ) and experience (i.e. $\triangle$ Operation, $\Delta$ Finance) are presented in Panel $\mathrm{C}$. The reported results are consistent with previously reported results in our Table 7 (see page 25). 
Table 8: Margin vs. Sales growers

\begin{tabular}{|c|c|c|c|c|c|c|c|c|}
\hline \multirow[t]{2}{*}{ Panel $A$} & \multicolumn{2}{|c|}{$A R O A$} & \multicolumn{2}{|c|}{ AROS } & \multicolumn{2}{|c|}{$A E M P G$} & \multicolumn{2}{|c|}{$A S A L G$} \\
\hline & 1 & 2 & 3 & 4 & 5 & 6 & 7 & 8 \\
\hline$P E D$ & $0.077(0.07)$ & $0.279 * *(0.117)$ & $-0.014(0.14)$ & $0.203(0.159)$ & $0.446^{* *}(0.208)$ & $0.567 * * *(0.198)$ & $0.798 * * *(0.244)$ & $0.676^{* * *}(0.177)$ \\
\hline$P E D^{*} B M$ argin & & $-0.157(0.105)$ & & $-0.161(0.182)$ & & $-0.104(0.161)$ & & $0.076(0.171)$ \\
\hline BMargin & $-0.043(0.029)$ & $0.000(0.042)$ & $-0.096 * *(0.048)$ & $-0.041(0.072)$ & $0.024(0.035)$ & $0.051(0.051)$ & $-0.137 * *(0.059)$ & $-0.107 *(0.063)$ \\
\hline Margin*Growth & $0.020(0.034)$ & $0.034(0.033)$ & $-0.098 * *(0.05)$ & $-0.084 *(0.047)$ & $0.008(0.040)$ & $0.013(0.041)$ & $-0.049(0.076)$ & $-0.027(0.069)$ \\
\hline PED*Poor ROA & & $-0.346 * * *(0.108)$ & & $-0.473(0.399)$ & & $-0.179(0.195)$ & & $-0.584 * *(0.262)$ \\
\hline Poor ROA & & $0.199 * * *(0.035)$ & & $0.212 * *(0.098)$ & & $0.098 *(0.053)$ & & $0.168 * *(0.071)$ \\
\hline Controls & included & included & included & included & included & included & included & Included \\
\hline Years & Yes & Yes & Yes & Yes & Yes & Yes & Yes & Yes \\
\hline$R^{2}(\%)$ & 15.94 & 28.65 & 13.9 & 16.6 & 27.93 & 28.2 & 21.59 & 26.99 \\
\hline Chi2 & $54.245 * * *$ & $95.551 * * *$ & 26.892 & 35.768 & $115.346^{* * *}$ & $108.398^{* * *}$ & $1316.693 * * *$ & $1475.367 * * *$ \\
\hline$N$ & 356 & 356 & 327 & 327 & 266 & 266 & 316 & 316 \\
\hline
\end{tabular}

\begin{tabular}{|c|c|c|c|c|c|c|c|c|}
\hline \multirow[t]{2}{*}{ Panel B } & \multicolumn{2}{|c|}{$A R O A$} & \multicolumn{2}{|c|}{ AROS } & \multicolumn{2}{|c|}{$A E M P G$} & \multicolumn{2}{|c|}{$A S A L G$} \\
\hline & 1 & 2 & 3 & 4 & 5 & 6 & 7 & 8 \\
\hline Finance & $0.058 * *(0.026)$ & $0.047(0.029)$ & $0.102 *(0.053)$ & $0.040(0.033)$ & $0.112(0.075)$ & $0.053(0.059)$ & $0.008(0.085)$ & $-0.053(0.074)$ \\
\hline Operation & $0.029(0.021)$ & $0.020(0.025)$ & $0.040(0.040)$ & $0.031(0.041)$ & $0.056(0.049)$ & $0.137 * * *(0.045)$ & $-0.023(0.069)$ & $0.074(0.071)$ \\
\hline$M B A$ & $-0.010(0.028)$ & $0.074 * *(0.037)$ & $-0.076(0.070)$ & $0.099(0.075)$ & $0.119^{* *}(0.051)$ & $0.073 *(0.042)$ & $0.217 * * *(0.075)$ & $0.117(0.08)$ \\
\hline Finance $^{*}$ BMargin & & $0.018(0.036)$ & & $0.113 *(0.063)$ & & $0.135(0.089)$ & & $0.154(0.109)$ \\
\hline Operation $*$ BMargin & & $0.005(0.032)$ & & $-0.018(0.064)$ & & $\begin{array}{l}- \\
0.184 * * *(0.068)\end{array}$ & & $-0.171 *(0.094)$ \\
\hline$M B A^{*} B M a r g i n$ & & $-0.124 * *(0.053)$ & & $-0.248 * *(0.111)$ & & $0.072(0.09)$ & & $0.169(0.114)$ \\
\hline BMargin & $-0.046(0.03)$ & $-0.023(0.043)$ & $-0.102 * *(0.05)$ & $-0.096(0.064)$ & $0.049(0.04)$ & $-0.008(0.063)$ & $-0.113 * *(0.057)$ & $-0.218 * *(0.106)$ \\
\hline Margin*Growth & $0.015(0.032)$ & $0.032(0.032)$ & $-0.114 * *(0.051)$ & $-0.078 *(0.042)$ & $0.042(0.046)$ & $0.045(0.043)$ & $-0.031(0.084)$ & $-0.026(0.079)$ \\
\hline Controls & included & included & included & included & included & included & included & included \\
\hline Years & Yes & Yes & Yes & Yes & Yes & Yes & Yes & Yes \\
\hline$R^{2}(\%)$ & 17.91 & 18.79 & 13.1 & 15.87 & 30.2 & 33.26 & 22.66 & 25.09 \\
\hline Chi2 & $75.463 * * *$ & $89.059 * * *$ & 32.045 & 38.163 & $99.902 * * *$ & $116.939 * * *$ & $1170.555^{* * *}$ & $1227.644^{* * *}$ \\
\hline$N$ & 356 & 356 & 327 & 327 & 266 & 266 & 316 & 316 \\
\hline
\end{tabular}




\begin{tabular}{|c|c|c|c|c|c|c|c|c|}
\hline \multirow[t]{2}{*}{ Panel $C$} & \multicolumn{2}{|c|}{$A R O A$} & \multicolumn{2}{|c|}{ AROS } & \multicolumn{2}{|c|}{$A E M P G$} & \multicolumn{2}{|c|}{$A S A L G$} \\
\hline & 1 & 2 & 3 & 4 & 5 & 6 & 7 & 8 \\
\hline AOperation & $0.029(0.025)$ & $0.039(0.035)$ & $0.012(0.044)$ & $0.042(0.061)$ & $0.020(0.041)$ & $0.098 *(0.055)$ & $-0.000(0.062)$ & $-0.063(0.063)$ \\
\hline AFinance & $-0.009(0.029)$ & $-0.043(0.029)$ & $-0.034(0.041)$ & $-0.082 * *(0.037)$ & $-0.032(0.038)$ & $-0.034(0.047)$ & $-0.094(0.062)$ & $-0.158 * *(0.078)$ \\
\hline$\triangle M B A$ & $0.061 * *(0.027)$ & $0.101 * * *(0.037)$ & $0.080(0.058)$ & $0.140 *(0.082)$ & $0.082 *(0.048)$ & $0.056(0.052)$ & $0.214 * * *(0.078)$ & $0.231 * *(0.095)$ \\
\hline$\Delta$ Finance $*$ BMargin & & $0.070(0.051)$ & & $0.091(0.078)$ & & $0.004(0.093)$ & & $0.117(0.121)$ \\
\hline DOperation*BMargin & & $-0.023(0.051)$ & & $-0.060(0.084)$ & & $-0.184 *(0.102)$ & & $0.113(0.124)$ \\
\hline$\triangle M B A^{*} B M$ argin & & $-0.072(0.052)$ & & $-0.108(0.108)$ & & $0.117(0.148)$ & & $-0.024(0.155)$ \\
\hline BMargin & $-0.042(0.028)$ & $-0.039(0.036)$ & $-0.095 * *(0.046)$ & $-0.078(0.06)$ & $0.029(0.035)$ & $0.054(0.045)$ & $-0.137 * *(0.057)$ & $-0.192 * *(0.082)$ \\
\hline Margin*Growth & $0.027(0.033)$ & $0.035(0.033)$ & $-0.089 * *(0.043)$ & $-0.073 *(0.039)$ & $0.019(0.043)$ & $0.026(0.047)$ & $-0.050(0.077)$ & $-0.051(0.073)$ \\
\hline Controls & included & included & included & included & included & included & included & included \\
\hline Years & Yes & Yes & Yes & Yes & Yes & Yes & Yes & Yes \\
\hline$R^{2}(\%)$ & 18.63 & 19.6 & 15.41 & 17.1 & 27.48 & 28.25 & 23.03 & 23.87 \\
\hline Chi2 & $58.864 * * *$ & $69.090 * * *$ & 31.027 & 32.398 & $119.02 * * *$ & $90.59 * * *$ & $1424.538^{* * *}$ & $1445.160^{* * *}$ \\
\hline$N$ & 356 & 356 & 327 & 327 & 266 & 266 & 316 & 316 \\
\hline
\end{tabular}

Notes: This table reports the results of the panel regression corrected for sample selection bias for the effect of PE directors and their human capital resources on post-SMBO performance, after interacting with the dummy variable of PE types (BMargin). BMargin is a dummy variable that takes one if the PE firm is margin focus and zero if the PE firm is growth focus. Control variable Margin*Growth is a dummy variable that equals one if a growth focus PE firm buys the company from a margin focus PE firm, and zero otherwise. The dependent variables (AROA, $A R O S$, $A E M P G$, and $A S A L G)$ are estimated as industry-adjusted abnormal performance measures. Panel A reports the results of the impact of PE directors. Panel B reports the results of the impact of human capital resources. Panel $\mathrm{C}$ reports the results of the impact of complementary human capital resources between the buying and selling PE firms. Model 1,3,5,7 of all Panels report the regression results without interaction term. Model 2,4,6,8 of all three Panels report the regression results after interacting BMargin with relevant variables for PE directors and their human capital resources. All the results are based on 99\% winsorized data. All parameters of panel regressions are estimated by a GLS random-effects model with robust standard error, omitted collinear covariates, and cluster by firm. All other control variables and entry year dummies are included. P-values for the Wald test are for probability $>$ Chi ${ }^{2}$. $N$ reports the number of firm-year observations in the panel regression model. ${ }^{*} \mathrm{p}<10 \%$; $* \mathrm{p}<5 \%,{ }^{* *} \mathrm{p}<1 \%$. Robust standard errors are reported in brackets. All variables are defined in Appendix 1 . 


\subsection{Pre-SMBO performance}

We further examine our findings on lack of statistical significance for Operational experience, and examine possibility that Operational skills could be valuable in poorly performing firms but not in well performing firms, which could erode the significance of the overall effect. The results are presented in Table 9. After including a categorical variable for poor performing pre-SMBO companies, our results for Operational experience remain consistent with the results reported in Table 7. MBA educational background however plays a particularly important role in the performance of poorly performing portfolio companies.

Table 9: Poor-performers (Poor_ROA)

Panel A: Experience and education- based human capital

\begin{tabular}{|c|c|c|c|c|}
\hline & $A R O A$ & AROS & $A E M P G$ & $A S A L G$ \\
\hline Finance & $0.058 * *(0.027)$ & $0.085 *(0.05)$ & $0.099(0.076)$ & $0.000(0.020)$ \\
\hline Operation & $-0.003(0.017)$ & $0.013(0.028)$ & $0.007(0.041)$ & $-0.034(0.067)$ \\
\hline$M B A$ & $-0.016(0.027)$ & $-0.095 *(0.056)$ & $0.038(0.041)$ & $0.157 * *(0.076)$ \\
\hline Finance $^{*}$ Poor_ROA & $-0.020(0.032)$ & $0.004(0.071)$ & $-0.153(0.106)$ & $0.053(0.128)$ \\
\hline Operation*Poor_ROA & $0.013(0.057)$ & $0.041(0.108)$ & $-0.11(0.119)$ & $-0.126(0.105)$ \\
\hline$M B A *$ Poor_ROA & $0.067(0.077)$ & $0.425 * *(0.175)$ & $0.481 * * *(0.142)$ & $0.129(0.13)$ \\
\hline Poor_ROA & $0.127 * * *(0.034)$ & $0.056(0.097)$ & $0.118 *(0.064)$ & $0.145(0.142)$ \\
\hline$L N B S$ & $-0.004(0.031)$ & $-0.020(0.060)$ & $-0.063(0.054)$ & $-0.029(0.062)$ \\
\hline Ind_outsiders & $-0.069(0.089)$ & $-0.052(0.095)$ & $0.412 * *(0.185)$ & $0.553 * *(0.231)$ \\
\hline MGTCHAN & $-0.017(0.021)$ & $0.017(0.031)$ & $-0.057 *(0.031)$ & $0.042(0.044)$ \\
\hline Insiders & $-0.057(0.056)$ & $-0.001(0.077)$ & $0.050(0.132)$ & $0.210(0.179)$ \\
\hline MGTSHARE & $0.049(0.047)$ & $0.046(0.048)$ & $0.072(0.068)$ & $0.103(0.080)$ \\
\hline GEAR & $-0.024 * * *(0.007)$ & $-0.021 * * *(0.008)$ & $-0.011(0.012)$ & $-0.024(0.018)$ \\
\hline LNDURATION & $-0.020(0.020)$ & $0.015(0.031)$ & $0.020(0.037)$ & $0.004(0.053)$ \\
\hline LNSIZE & $-0.001(0.013)$ & $-0.029(0.023)$ & $0.008(0.019)$ & $0.020(0.030)$ \\
\hline Crisis & $-0.010(0.012)$ & $0.006(0.013)$ & $-0.086 *(0.045)$ & $-0.112 *(0.060)$ \\
\hline Lambda & $-0.013(0.057)$ & $-0.158 *(0.085)$ & $0.010(0.1030)$ & $0.184(0.132)$ \\
\hline Intercept & $-0.189(0.263)$ & $0.002(0.182)$ & $-0.015(0.246)$ & $-0.626 * *(0.319)$ \\
\hline Years & Yes & Yes & Yes & Yes \\
\hline$R^{2}(\%)$ & 18.8 & 19.5 & 22.59 & 19.76 \\
\hline Chi2 & $78.348 * * *$ & $65.956^{* * *}$ & $219.527 * * *$ & $80.700 * * *$ \\
\hline$N$ & 450 & 402 & 335 & 377 \\
\hline
\end{tabular}


Panel B: Complementarity of human capital

\begin{tabular}{|c|c|c|c|c|}
\hline & $A R O A$ & AROS & AEMPG & $A S A L G$ \\
\hline AFinance & $0.027(0.022)$ & $0.011(0.025)$ & $0.009(0.043)$ & $0.021(0.06)$ \\
\hline AOperation & $0.040(0.027)$ & $0.035(0.033)$ & $0.043(0.042)$ & $-0.056(0.062)$ \\
\hline$\triangle M B A$ & $0.023(0.026)$ & $-0.015(0.034)$ & $0.015(0.051)$ & $0.131 *(0.079)$ \\
\hline$\triangle$ Finance*Poor_ROA & $-0.124 * *(0.049)$ & $-0.132(0.09)$ & $-0.207 * *(0.086)$ & $-0.021(0.118)$ \\
\hline$\Delta O p e r a t i o n *$ Poor_ROA & $0.028(0.058)$ & $0.052(0.099)$ & $-0.128(0.102)$ & $-0.087(0.125)$ \\
\hline$\triangle M B A *$ Poor_ROA & $0.003(0.064)$ & $0.393 * * *(0.141)$ & $0.269 *(0.144)$ & $0.026(0.205)$ \\
\hline Poor_ROA & $0.155^{* * *}(0.038)$ & $0.095(0.095)$ & $0.135 * *(0.061)$ & $0.169 *(0.098)$ \\
\hline$L N B S$ & $0.011(0.029)$ & $-0.005(0.045)$ & $0.008(0.043)$ & $0.009(0.07)$ \\
\hline Ind_outsiders & $-0.053(0.088)$ & $-0.043(0.097)$ & $0.186(0.135)$ & $0.540 * *(0.231)$ \\
\hline MGTCHAN & $-0.015(0.021)$ & $0.013(0.031)$ & $-0.054 * *(0.026)$ & $0.028(0.043)$ \\
\hline Insiders & $-0.082 *(0.044)$ & $-0.040(0.077)$ & $-0.038(0.072)$ & $0.185(0.134)$ \\
\hline MGTSHARE & $0.053(0.048)$ & $0.059(0.047)$ & $0.044(0.06)$ & $0.085(0.082)$ \\
\hline GEAR & $-0.024 * * *(0.006)$ & $-0.021 * * *(0.008)$ & $-0.005(0.01)$ & $-0.027(0.018)$ \\
\hline LNDURATION & $-0.025(0.02)$ & $0.014(0.031)$ & $0.000(0.015)$ & $0.012(0.049)$ \\
\hline LNSIZE & $-0.002(0.011)$ & $-0.028(0.022)$ & $0.005(0.02)$ & $0.019(0.032)$ \\
\hline Crisis & $-0.013(0.012)$ & $0.001(0.018)$ & $-0.089 * *(0.041)$ & $-0.115 *(0.063)$ \\
\hline Lambda & $-0.035(0.056)$ & $-0.188 * *(0.093)$ & $-0.028(0.098)$ & $0.172(0.13)$ \\
\hline Intercept & $-0.157(0.261)$ & $0.051(0.206)$ & $0.012(0.207)$ & $-0.659 * *(0.316)$ \\
\hline Years & Yes & Yes & Yes & Yes \\
\hline$R^{2}(\%)$ & 19.37 & 23.26 & 21.29 & 18.02 \\
\hline Chi2 & $65.991 * * *$ & $75.562 * * *$ & $217.453 * * *$ & $86.891 * * *$ \\
\hline$N$ & 450 & 402 & 335 & 377 \\
\hline
\end{tabular}

Notes: This table reports the results of the panel regression corrected for sample selection bias for the effect of PE human capital resources and complementary of human capital on post-SMBO performance, after interacting with the dummy variable for poor performing pre-SMBO companies (Poor_ROA). The dependent variables (AROA, AROS, AEMPG, and $A S A L G)$ are estimated as industry-adjusted abnormal performance measures. Lambda is the fitted probability of receiving PE backing, estimated from the Probit regression model in Table 6. Panel A reports the results of the impact of human capital resources, after interacting with Poor_ROA. Panel B reports the results of the impact of complementary human capital resources between the buying and selling PE firms, after interacting with Poor ROA. All the results are based on $99 \%$ winsorized data. All parameters of panel regressions are estimated by a GLS random-effects model with robust standard error, omitted collinear covariates, and cluster by firm. Entry year dummies are included. P-values for the Wald test are for probability $>\mathrm{Chi}^{2} . N$ reports the number of firm-year observations in the panel regression model. ${ }^{*} \mathrm{p}<10 \% ; * * \mathrm{p}<5 \%, * * *$ $\mathrm{p}<1 \%$. Robust standard errors are reported in brackets. All variables are defined in Appendix 1.

\subsection{Other robustness checks}

Some previous studies suggest that the monitoring role should play a larger role in deals where managerial ownership is greater, as this creates more agency problems. We therefore repeated our estimates in subsamples with large (i.e. top quartile) and small (i.e. bottom quartile) management ownership stakes. Our results suggest stronger link between directors with financial expertise and increased profitability in deals with higher agency costs.

We also repeat our estimates after controlling for both Ind_outsiders and other outsiders.

Unreported results suggest that our results remain robust. 


\section{Discussion and conclusion}

This is, to the best of our knowledge, the first paper providing evidence that PE partners and executives as directors play important monitoring and advisory roles in post-SMBO performance. We make several contributions.

First, we add to literature on the sustainability of corporate governance by exploring the changing nature of PE partners and executives on boards in the SMBO context. Building on the complementarity between agency and strategic entrepreneurship perspectives, we suggest that PE directors help in providing both close monitoring and better advice on mitigating agency costs and exploiting growth opportunities in SMBOs. Our findings provide support and clearly highlight the importance of PE directors for performance improvements, and growth performance especially. For instance, we show that the fraction of PE directors has a positive impact on post-SMBO employment and sales growth. Results regarding poorly performing buyouts show they require more PE directors to increase the same level of growth ratios than other deals, suggesting that monitoring and advisory roles of PE directors are necessary to improve performance.

Further, we reveal the importance of exploring the heterogeneity of human capital within PE firms rather than treating particular PE firms as homogeneous. Consistent with previous studies (Acharya et al., 2013), we find that human capital of PE directors matters, especially PE directors with high level business education in relation to growth. However, consistent with Degeorge, Martin and Phalippou (2016) we find no significantly positive effects of PE directors' operational experience on post SMBO performance. Complementarity in buying and selling PE firms works in relation to high level business education, and only weakly in 
respect to operational experience.

However, in contrast with Degeorge, Martin and Phalippou (2016) we do not find strong evidence of the impact of a complementary financial and operational set of skills on postSMBO performance. It could be that Degeorge, Martin and Phalippou (2016) treat the PE firm as a whole and their human capital variables are measured only at PE firm level. By using portfolio companies (i.e. buyouts) level data we examine the importance of human capital at board (i.e. deal) level. This yielded interesting results that PE firms with a growth focus tend to appointing significantly more directors with an MBA degree, while directors with an MBA have a particularly significant impact in SMBOs that were previously poorly performing buyouts.

We also examine the impact of human capital on specific aspects of performance akin to agency (e.g. profitability) and entrepreneurship (e.g. growth) perspectives. Separate examination of the impact of human capital on different aspects of performance is not possible based on composite measures obtained from PE firms (i.e. internal rate of return (IRR)). In addition, by relying on publicly available (and audited) accounting data on portfolio companies we avoid selection bias associated with obtaining data from PE firms and/or investors.

Second, we extend board research showing the importance of human capital composition (e.g. Chahine and Goergen, 2011; Knockaert and Ucbasaran, 2013) to a new context. In particular, we add to growing evidence that to understand the sustainability of boards fulfilling their roles (Goergen and Renneboog, 2014). It is important to consider the ownership and life-cycle nature of the firm concerned. Prior studies have considered a variety 
of entrepreneurial firm types such as high tech startups (e.g. Bertoni, Colombo and Croce, 2013; Knockaert, Bjornali and Erikson, 2015; Knockaert and Ucbasaran, 2013), VC backed firms (Chahine and Goergen, 2011) and family firms (Bammens, Voordeckers and Van Gils, 2011; Wilson, Wright and Scholes, 2013). SMBOs extend these contexts to introduce a dynamic aspect by recognizing that entrepreneurial firms transitioning to a next stage in their life-cycle experience specific changes in their boards' human capital composition that impact performance.

Third, we extend the agency theory perspective by incorporating the strategic entrepreneurship perspective as a complementary theory in the SMBO context, and as such we respond to calls for more multi-theoretical work on corporate governance. Agency theory suggests SMBO are unlikely to make significant further performance improvement due to the exhausted benefits from agency costs reduction in the primary buyout (Wang, 2012; Achleitner and Figge, 2014). We argue agency conflicts may still exist in SMBOs and, according to the strategic entrepreneurship perspective (Wright, Hoskisson and Busenitz, 2001; Meuleman et al., 2009), new PE partners and executives may bring new resources and capacities to identify and exploit growth opportunities. Hence, there is still performance improvement potential. Moreover, prior works focus on the financial monitoring role of PE partners and executives on board and its effect on profitable efficiency almost exclusively examines primary buyouts (Guo, Hotchkiss and Song, 2011; Cornelli and Karakaş, 2013).

Our findings have managerial implications regarding the sustainability of boards involving PE directors. High level business education appears an important human capital resource of PE directors to improve post-SMBO growth performance. Financial experts skilled in financial monitoring and cost-cutting strategies can continue to squeeze the cost-cutting 
potentials of SMBOs to improve profitability. However, we do not find financial experience contributes to growth performance, inconsistent with the argument that financial experts are specialized in growth through M\&A deals. Given the importance of M\&A for growth in SMBOs (Wang, 2012), our findings that financial experience does not contribute to growth performance emphasizes the need to focus on the right PE director expertise to realize growth opportunities. The implication from our surprising finding of no strong evidence that operational experience improves performance especially revenue growth is that operational PE directors may not have the specific expertise and skills required by their portfolio companies to boost revenue growth. Instead, the implication is for PE firms to introduce independent directors with skills that complement the absent operational skills of their own staff. As a significant part of the UK economy therefore, our findings have important implications in considering how firms and their financial backers recruit the most appropriate members of the board team to make a positive social and economic impact, particularly with respect to the role of independent directors.

We also acknowledge some limitations of our study which suggest avenues for further research. First, our analysis does not distinguish types of growth strategies. Prior studies indicate that various PE partners and executives have various expertise on growth strategies. For instance, financial experts prefer acquisitions while operational experts are specialized in organic growth strategies such as revenue growth. Further research may try to obtain data to associate the human capital of PE partners and executives with specific growth strategies they use for their portfolio companies. Second, although we find that SMBOs benefit from the monitoring and advice of PE directors, we do not entirely separate the impact of monitoring and advice. We do however report an important advisory role of independent outsiders (active CEOs of other (non-affiliated) companies, consultants, businessmen and university 
professors), in line with our argument that agency/monitoring issues are likely to be addressed in the primary buyouts and that, therefore, the advisory role plays is more important in SMBOs.

We also do not directly examine how PE directors use their expertise and skills to collaborate with other board members and/or top managers and facilitate the decision making process. Further research would benefit from directly investigating the roles of PE directors on board decision making process. Third, the measures we use for human capital of PE directors are generic. Specifically regarding the operational experience, we are unable to check the specific operational experience such as sales, marketing, innovation, or industry. Future research may seek to match the specific experience of PE directors with growth strategies and performance effects. Fourth, we examine some human capital factors of PE directors. PE directors also have other human capital factors. For instance, PE directors with international expansion experience may give a better knowledge and skills that facilitate the international expansion of some SMBOs.

Despite these limitations, our paper demonstrates that governance benefits are not exhausted in primary buyouts but the effects in secondary buyouts depend on the nature of PE directors' human capital resource, notably in respect of the balance between board monitoring and advisory roles. Our study thus helps develop understanding of the importance of taking a fine-grained perspective of human capital resources of PE directors in future research on corporate governance sustainability. 


\section{References}

Acharya, V. V., O. F. Gottschalg, M. Hahn and C. Kehoe (2013). 'Corporate governance and value creation: evidence from private equity', Review of Financial Studies, 26, pp. 368-402.

Achleitner, A. K. and C. Figge (2014). 'Private equity lemons? evidence on value creation in secondary buyouts', European Financial Management, 20, pp. 406-433.

Achleitner, A.-K., C. Figge and E. Lutz (2012). 'Drivers of value creation in a secondary buyout: the acquisition of Brenntag by BC Partners', Working Paper, Technische Universität München.

Aguilera, R., I. Filatotchev, H. Gospel and G. Jackson (2008). 'An organizational approach to comparative corporate governance: costs, contingencies and complementarities', Organization Science, 19, pp. 475-492.

Ahlers, O., A. Hack, K. Madison, M. Wright and F. W. Kellermanns (2016). 'Is it all about money?-affective commitment and the difference between family and non-family sellers in buyouts', British Journal of Management, DOI: 10.1111/1467-8551.12178.

Arcot, S., Z. Fluck, J.-M. Gaspar and U. Hege (2015). 'Fund managers under pressure: rationale and determinants of secondary buyouts', Journal of Financial Economics, 115, pp. 102-135.

Bammens, Y., W. Voordeckers and A. Van Gils (2011). 'Boards of directors in family businesses: a literature review and research agenda', International Journal of Management Reviews, 13, pp. 134-152.

Barber, B. M. and J. D. Lyon (1996). 'Detecting abnormal operating performance: the empirical power and specification of test statistics', Journal of Financial Economics, 41, pp. 359-399.

Barney, J. B. (2014). Gaining and Sustaining Competitive Advantage. Harlow, Essex: Pearson.

Bayar, O. and T. Chemmanur (2006). 'IPOs or acquisitions? a theory of the choice of exit strategy by entrepreneurs and venture capitalists', Working Paper, Boston College.

Becker, G. S. (1975). Human Capital: A Theoretical and Empirical Analysis, with Special Reference to Education. New York: National Bureau of Economic Research.

Bertoni, F., M. G. Colombo and A. Croce (2013). 'Corporate governance in high-tech firms', In M. Wright, D. S. Siegel, K. Keasey and I. Filatotchev (eds), The Oxford Handbook of Corporate Governance. Oxford: Oxford University Press.

Bertrand, M. and A. Schoar (2003). 'Managing with style: the effect of managers on firm policies', The Quarterly Journal of Economics, 118, pp. 1169-1208.

Bienz, C. (2004). 'A pecking order of venture capital exits-what determines the optimal exit channel for venture capital backed ventures?', German Research, 49, pp. 1-17.

Bonini, S. (2015). 'Secondary buyouts: operating performance and investment determinants', Financial Management, 44, pp. 431-470.

Bruining, H. and M. Wright (2002). 'Entrepreneurial orientation in management buy-outs and the contribution of venture capital', Venture Capital: An International Journal of Entrepreneurial Finance, 4, pp. 147-168.

Chahine, S. and M. Goergen (2011). 'VC Board representation and performance of US IPOs', Journal of Business Finance and Accounting, 38, pp. 413-445. 
Clarysse, B., M. Knockaert and A. Lockett (2007). 'Outside board members in high tech startups', Small Business Economics, 29, pp. 243-259.

CMBOR (2016). European Buy-Outs Report. London: the Centre for Management Buy-out Research.

Cornelli, F. and O. Karakaş (2013). 'Corporate governance of LBOs: the role of boards', Working Paper, London Business School and Boston College.

Cressy, R., F. Munari and A. Malipiero (2007). 'Playing to their strengths? evidence that specialization in the private equity industry confers competitive advantage', Journal of Corporate Finance, 13, pp. 647-669.

Cumming, D., D. S. Siegel and M. Wright (2007). 'Private equity, leveraged buyouts and governance', Journal of Corporate Finance, 13, pp. 439-460.

de Villiers, C., V. Naiker and C. J. van Staden (2011). 'The effect of board characteristics on firm environmental performance', Journal of Management: DOI: $10.1177 / 0149206311411506$.

Degeorge, F., J. Martin and L. Phalippou (2016). 'On secondary buyouts', Journal of Financial Economics, 120, pp. 124-145.

Delmar, F., P. Davidsson and W. B. Gartner (2003). 'Arriving at the high-growth firm', Journal of Business Venturing, 18, pp. 189-216.

Dushnitsky G. and J.M. Shaver (2009). 'Limitations to interorganizational knowledge acquisitions: the paradox of corporate venture capital', Strategic Management Journal, 30, pp. 1045-1064.

Eslayed, K. (2010). 'A multi-theory perspective of board leadership structure: what does the egyptian corporate governance context tell us?', British Journal of Management, 21, pp. 80-99.

Fama, E. F. and K. R. French (2001). 'Forecasting profitability and earnings', The Journal of Business, 73, pp. 161-175.

Filatotchev, I. (2006). 'Effects of executive characteristics and venture capital involvement on board composition and share ownership in IPO firms', British Journal of Management, 17, pp. 75-92.

Goergen, M., N. O'Sullivan and G. Wood (2014). 'The employment consequences of private equity acquisitions: the case of institutional buy outs', European Economic Review, 71, pp. 67-79.

Goergen, M. and L. Renneboog (2014). 'Inside the board room', Journal of Corporate Finance, 28, pp. 1-5.

Gompers, P., A. Kovner, J. Lerner and D. Scharfstein (2008). 'Venture capital investment cycles: the impact of public markets', Journal of Financial Economics, 87, pp.1-23.

Gong, J. J. and S. Y. Wu (2011). 'CEO turnover in private equity sponsored leveraged buyouts', Corporate Governance: An International Review, 19, pp. 195-209.

Guo, S., E. S. Hotchkiss and W. Song (2011). 'Do buyouts (still) create value?', The Journal of Finance, 66, pp. 479-517.

Hambrick, D. C. and P. A. Mason (1984). 'Upper echelons: the organization as a reflection of its top managers', Academy of Management Review, 9, pp. 193-206.

Harford, J. and A. Kolasinski (2013). 'Do private equity returns result from wealth transfers and short-termism? Evidence from a comprehensive sample of large buyouts', Management Science, 60, pp. 888-902.

Harris, R., D. S. Siegel and M. Wright (2005). 'Assessing the impact of management buyouts on economic efficiency: plant-level evidence from the United Kingdom', Review of Economics and Statistics, 87, pp. 148-153.

Heckman, J. (1979). 'Sample selection bias as a specification error', Econometrica, 47, pp. 153-161. 
Hendry, J. (2005). 'Beyond self-interest: agency theory and the board in a satisficing world', British Journal of Management, 16, pp. 55-63.

Hillman, A. J. and T. Dalziel (2003). 'Boards of directors and firm performance: integrating agency and resource dependence perspectives', Academy of Management Review, 28, pp. 383-396.

Hitt, M. A., R. D. Ireland, S. M. Camp and D. L. Sexton (2001). 'Strategic entrepreneurship: entrepreneurial strategies for wealth creation', Strategic Management Journal, 22, pp. 479-491.

Ireland, R. D., M. A. Hitt, S. M. Camp and D. L. Sexton (2001). 'Integrating entrepreneurship and strategic management actions to create firm wealth', The Academy of Management Executive, 15, pp. 49-63.

Ireland, R. D., M. A. Hitt and D. G. Sirmon (2003). 'A model of strategic entrepreneurship: the construct and its dimensions', Journal of Management, 29, pp. 963-989.

Jelic R. (2011). 'Staying power of UK buy-outs', Journal of Business Finance and Accounting, 38, pp. 945-986.

Jelic, R. and M. Wright (2011). 'Exits, performance, and late stage private equity: the case of UK management buy-outs', European Financial Management, 17, pp. 560-593.

Jenkinson, T. and M. Sousa (2015). 'What determines the exit decision for leveraged buyouts?', Journal of Banking and Finance, 59, pp. 399-408.

Jensen, M. C. (1989). 'Eclipse of the public corporation', Harvard Business Review, 67, pp. $61-74$.

Johnson, S.G., K. Schnatterly and A.D. Hill (2013). 'Board composition beyond independence social capital, human capital, and demographics', Journal of Management, 39, pp. 232-262.

Kaplan, S. N. and P. Strömberg (2009). 'Leveraged buyouts and private equity', The Journal of Economic Perspectives, 23, pp. 121-146.

Knockaert, M., E. S. Bjornali and T. Erikson (2015). 'Joining forces: top management team and board chair characteristics as antecedents of board service involvement', Journal of Business Venturing, 30, pp. 420-435.

Knockaert, M. and D. Ucbasaran (2013). 'The service role of outside boards in high tech start-ups: a resource dependency perspective', British Journal of Management, 24, pp. 69-84.

Kroll, M., B. A. Walters and P. Wright (2008). 'Board vigilance, director experience, and corporate outcomes', Strategic Management Journal, 29, pp. 363-382.

Lerner, J. (1995). 'Venture capitalists and the oversight of private firms', The Journal of Finance, 50, pp. 301-318.

Masulis, R. W. and S. Mobbs (2011). 'Are all inside directors the same? evidence from the external directorship market', The Journal of Finance, 66, pp. 823-872.

McNulty, T. and A. Pettigrew (1999). 'Strategists on the board', Organization Studies, 20, pp. 47-74.

Meuleman, M., K. Amess, M. Wright and L. Scholes (2009). 'Agency, strategic entrepreneurship, and the performance of private equity-backed buyouts', Entrepreneurship Theory and Practice, 33, pp. 213-239.

Morck, R., A. Shleifer and R. W. Vishny (1988). 'Management ownership and market valuation: an empirical analysis', Journal of Financial Economics, 20, pp. 293-315.

O'Connell, V. and N. Cramer (2010). 'The relationship between firm performance and board characteristics in Ireland', European Management Journal, 28, pp. 387-399.

Palmer, D. and B. M. Barber (2001). 'Challengers, elites, and owning families: a social class theory of corporate acquisitions in the 1960s', Administrative Science Quarterly, 46, pp. 87-120. 
Parti Socialist Europeen (PSE) (2007). Hedge Funds and Private Equity: A Critical Analysis. Brussels: Socialist Group in the European Parliament.

Rappaport, A. (1990). 'The staying power of the public corporation', Harvard Business Review, 68, pp. 96-104.

Siegel, D., M. Wright and I. Filatotchev (2011). 'Private equity, LBOs, and corporate governance: international evidence', Corporate Governance: An International Review, 19, pp. 185-194.

Strömberg P. (2008). 'The new demography of private equity', In Lerner J. and A. Gurung (eds) Globalization and Alternative Investments, Working Papers Volume 1, The Global Impact of Private Equity Report 2008. New York: World Economic Forum USA Inc..

Tian, J. J., J. J. Haleblian and N. Rajagopalan (2011). 'The effects of board human and social capital on investor reactions to new CEO selection', Strategic Management Journal, 32, pp. 731-747.

Toms, S., N. Wilson and M. Wright (2015). 'The evolution of private equity: corporate restructuring in the UK, c. 1945-2010', Business History, 57, pp. 736-768.

Wang, Y. (2012). 'Secondary buyouts: why buy and at what price?', Journal of Corporate Finance, 18, pp. 1306-1325.

Wilson, N., M. Wright and L. Scholes (2013). 'Family business survival and the role of boards', Entrepreneurship Theory and Practice, 37, pp. 1369-1389.

Wincent, J., S. Anokhin and D. Örtqvist (2010). 'Does network board capital matter? a study of innovative performance in strategic SME networks', Journal of Business Research, 63, pp. 265-275.

Wood, G. and M. Wright (2010). 'Private equity and human resource management: an emerging agenda', Human Relations, 63(9), pp. 1279-1296.

Wright, M., R. E. Hoskisson and L. W. Busenitz (2001). 'Firm rebirth: buyouts as facilitators of strategic growth and entrepreneurship', The Academy of Management Executive, 15, pp. 111-125.

Wright, M., R. E. Hoskisson, L. W. Busenitz and J. Dial (2000). 'Entrepreneurial growth through privatization: the upside of management buyouts', Academy of Management Review, 25, pp. 591-601.

Wright, M., R. E. Hoskisson, L. W. Busenitz and J. Dial (2001). 'Finance and management buyouts: agency versus entrepreneurship perspectives', Venture Capital: An International Journal of Entrepreneurial Finance, 3, pp. 239-261.

Zahra, S. A., E. Gedajlovic, D. O. Neubaum and J. M. Shulman (2009). 'A typology of social entrepreneurs: motives, search processes and ethical challenges', Journal of Business Venturing, 24, pp. 519-532.

Zattoni, A. and F. Cuomo (2010). 'How independent, competent and incentivized should nonexecutive directors be? an empirical investigation of good governance codes', British Journal of Management, 21, pp. 63-79.

Zhou, D., R. Jelic and M. Wright (2014). 'SMBOs: buying time or improving performance?', Managerial and Decision Economics, 35, pp. 88-102.

Zona, F., A. Zattoni and A. Minichilli (2013). 'A contingency model of boards of directors and firm innovation: the moderating role of firm size', British Journal of Management, 24, pp. 299-315. 
Appendix 1: Definition of variables

\section{\begin{tabular}{l} 
Description Variab \\
\hline Performance measures
\end{tabular} \\ Profitability}

Abnormal return $A R O A$

on assets

Abnormal return AROS

on sales

\section{Growth}

Abnormal

AEMPG

employment

growth

Abnormal sales $A S A L G$ growth

Independent

variables
$A R O A$ is difference between a company actual and expected ROA, in postSMBO years (Barber and Lyon, 1996). ROA is a company's earnings before interests and taxes (EBIT) scaled by the total assets in the same year. Expected ROA is a company's median ROA, during 3-year period before the $\mathrm{SMBO}$, adjusted for the change in ROA in a respective industry. The industry's change is the difference between median ROA of the industry in each of the post-SMBO years and the industry's 3-year median ROA before SMBO. Sample SMBOs are classified into nine broad industries in line with the management and technology expertise in the venture capital industry (Gompers et al., 2008).

$A R O S$ is difference between a company actual and expected ROA, in postSMBO years (Barber and Lyon, 1996). ROS is a company's earnings before interests and taxes (EBIT) scaled by the total sales in the same year. Expected ROS is a company's median ROS, during 3-year period before the SMBO, adjusted for the change in ROS in a respective industry. The industry's change is the difference between median ROS of the industry in each of the post-SMBO years and the industry's 3-year median ROS before SMBO. Sample SMBOs are classified into nine broad industries in line with the management and technology expertise in the venture capital industry (Gompers et al., 2008).

$A E M P G$ is difference between a company actual and expected EMPG, in post-SMBO years (Barber and Lyon, 1996). EMPG is the difference between the company's end of year number of employees in year $t$ and year $t-1$, scaled by the average of number of employees in year $t$ and $t-1$. Expected EMPG is a company's median EMPG, during 3-year period before the SMBO, adjusted for the change in EMPG in a respective industry. The industry's change is the difference between median EMPG of the industry in each of the post-SMBO years and the industry's median EMPG before SMBO. Sample SMBOs are classified into nine broad industries in line with the management and technology expertise in the venture capital industry (Gompers et al., 2008). $A S A L G$ is difference between a company actual and expected SALG, in postSMBO years (Barber and Lyon, 1996). SALG is the difference between the company's sales in year $t$ and year $t-1$, scaled by the average of sales in year $t$ and $\mathrm{t}-1$. Expected SALG is a company's median SALG, during 3-year period before the SMBO, adjusted for the change in SALG in a respective industry. The industry's change is the difference between median SALG of the industry in each of the post-SMBO years and the industry's median SALG before SMBO. Sample SMBOs are classified into nine broad industries in line with the management and technology expertise in the venture capital industry (Gompers et al., 2008). 
The percentage of PE directors on the board

Financial experience

Finance

A_Finance

Operational

experience

Operation

$\Delta$ Operation

High level $M B A$

business

education

$\triangle M B A$

\section{Controls}

Board size

$L N B S$

The percentage

of independent

outsiders

Change in top MGTCHAN

management

The percentage

of inside

directors

Management

share

Leverage

GEAR

Business service BSERVICES industry

Companies'size LNSIZE

Financial crisis Crisis

Pre-SMBO Pre_ROA

performance

Poor_ROA

Longevity of DURATION

buyouts
The number of PE partners and executives who appear on PE firms' payroll divided by board size in year $t$.

A categorical variable taking the value of 1 if at least one PE director in year $t$ worked in finance, accounting or banking related job before joining PE industry, and 0 otherwise.

A categorical variable taking the value of 1 if at least one buying PE director in year $t$ has financial experience, while all selling PE directors do not have.

A categorical variable taking the value of 1 if at least one PE director on the board in year $t$ at least once in his or her professional career worked in a consulting (a company designated as providing consulting services) or industry job that was not finance, accounting or banking related before joining PE industry, and 0 otherwise.

A categorical variable taking the value of 1 if at least one buying PE director in year $\mathrm{t}$ has operational experience while all selling PE directors do not have.

A categorical variable taking the value of 1 if at least one PE director in year $\mathrm{t}$ holds a MBA degree, and 0 otherwise.

A categorical variable taking the value of 1 if at least one buying PE director in year $t$ has MBA degree, while all selling PE directors do not have.

The natural logarithm of the number of directors on SMBO board in year $t$.

The number of independent outside directors without obvious relationships with sample portfolio companies (e.g. active CEOs of other (non-affiliated) companies, consultants, businessmen and university professors), divided by board size in year $\mathrm{t}$.

A categorical variable which equals 1 if the CEO and/or CFO is replaced within three years after the relevant SMBO transaction year, and 0 otherwise.

The number of inside directors divided by board size in year $\mathrm{t}$.

The percentage of target company's common equity contributed by the management in year $\mathrm{t}$.

The sum of long term and short term debt divided by the total equity in year $\mathrm{t}$.

A categorical variable equals 1 for a SMBO from Business Service industry and 0 otherwise.

The natural logarithm of SMBO value in $£$ million.

A categorical variable which equals 1 for observations from 2008-2010.

The performance ratio in the form of industry adjusted $R O A$ in year preceding the SMBO transaction.

A categorical variable if $\operatorname{Pre}-\mathrm{ROA}$ is smaller than its median value and 0 otherwise.

The number of months from the SMBO date to the exit date, if the SMBO was exited; or the number of months from the SMBO date to the sample's cut-off date $(30 / 06 / 2015)$, if the SMBO was not exited.

LNDURATION The natural logarithm of DURATION. 


\begin{tabular}{|c|c|c|c|}
\hline \multicolumn{2}{|l|}{ Lambda } & Lambda & The fitted probability of receiving PE backing, estimated by Probit model. \\
\hline \multicolumn{2}{|l|}{ Deal Type } & BUYIN & A categorical variable which equals 1 if the SMBO is a buy-in. \\
\hline $\begin{array}{l}\text { Previous } \\
\text { backing }\end{array}$ & $\mathrm{PE}$ & Pre_PE & $\begin{array}{l}\text { A categorical variable that takes } 1 \text { if a SMBO is PE backed in primary stage; } \\
\text { and } 0 \text { otherwise. }\end{array}$ \\
\hline \multirow[t]{2}{*}{$\begin{array}{l}\text { Types } \\
\text { firms }\end{array}$} & $\mathrm{PE}$ & BMargin & $\begin{array}{l}\text { A categorical variable that takes } 1 \text { if the buying PE firm focuses on margin } \\
\text { and } 0 \text { if the buying PE firm focuses on growth. }\end{array}$ \\
\hline & & $\begin{array}{l}\text { Margin } \\
\text { *Growth }\end{array}$ & $\begin{array}{l}\text { A categorical variable that takes } 1 \text { if the selling PE firm focuses on margin } \\
\text { while the buying PE firm focuses on growth, and } 0 \text { otherwise. }\end{array}$ \\
\hline
\end{tabular}

